\title{
Contingent Fees for Expert Witnesses in Civil Litigation
}

\author{
Assistance of nonlegal experts is essential to effective litigation of
} many disputes. ${ }^{1}$ Doctors in personal injury suits, accountants in stockholder derivative suits, economists in antitrust suits, to name just a few, provide specialized knowledge to the lay adjudicatory system. Such expert assistance can be so costly, ${ }^{2}$ however, that it represents a

1. The necessity for cxpert testimony in civil litigation is widely recognized. See, e.g., American Bar foundatron, Public Provision for Costs and Expenses of Civil Litigation 1 (1966) (expert witnesses are among "auxiliary services . . . indispensible or practically necessary" to maintain civil action) [hereinafter cited as Public Provision]; D. Doud, Scientific Evidence 1 (Wis. Law. Seminars 1959) (expert evidence "a controlling factor in $65 \%$ of all court litigation"); IA J. Kelner, Successful Litigation Technigues 126.2 (1976) (use of expert testimony "absolutely essential in many cases"); Rosenthal, The Development of the Use of Expert Testimony, 2 Law \& Contemp. ProB. 403, 405 (1935) ("[T] fiat for expert testimony is necessity, born of the realization that the effective administration of justice requires aid from other branches of learning and science.")

Courts have noted the critical role of expert testimony in the cases before them. See, e.g., Person v. Association of Bar, 414 F. Supp. 144, 145 (E.D.N.Y. 1976), rev'd on other grounds, 554 F.2d 534 (2d Cir. 1977) ("[E]xpert testimony is either essential or necessary to the best and most effective presentation of [some kinds of cases.]"; accounting and economic testimony required for antitrust suit); National Soda Prods. Co. v. City of Los Angeles, 109 Cal. App. 2d 440, 443, 240 P.2d 993, 995 (1952) ("It has long been recognized that expert testimony is not only proper but also virtually indispensible in cases where the relation between the facts and results may be understood only by those with special skill or training."; civil engineers). But few causes of action require expert testimony as a matter of law. See Salem v. United States Lines Co., 370 U.S. 3I, 35 (1962); 7 J. Wigmore, Evidence $\$ \S 2090$, 2090a (3d ed. 1940).

For examples of types of questions which may require expert testimony and for an idea of the variety of experts employed in litigation, see 1 R. MILLER, Lawyers' Source BooK (1971) (directory of expert services); Gair, Selecting and Preparing Expert Witnesses $§ \S 17,18$, in 2 AM. Jur. Trials 585 (1964) (same).

2. The size of expert fees depends upon the requirements of the specific case or the type of litigation. See, e.g., Burgess v. Williamson, 506 F.2d 870, 879 (5th Cir. 1975) $(\$ 20,000$, accountant); Osguthorpe v. Anschutz Land \& Livestock Co., 456 F.2d 996, 1004 (10th Cir. 1972) (\$25,000, reterinarian); Brief for Plaintiff-Appellee at 4, Person v. Association of Bar, 554 F.2d 534 (2d Cir. 1977) $(\$ 40,000$ to $\$ 60,000$, antitrust economists and accountants) [hereinafter cited as Brief for Plaintiff]; J. BrenNas, The Cost of the American Judicial System I1, 73-74 (1966) (describing two personal injury cases, one requiring $\$ 250$ for medical testimony; the other, $\$ 975$ for medical examination, consultation, and testimony); D. Rosenthal, Lawyer and Client: Who's in Charge? 108 (1974) (medical testimony in personal injury cases "as much as $\$ 400 "$ "). But see Franklin, Chanin \& Mark, Accidents, Money, and the Law: A Study of the Economics of Personal Injury Litigation, 61 Colum. L. Rev, I, $21 \mathrm{n} .99$ (1961) (costs and expenses including expert testimony exceeded $\$ 100$ in only 123 of 1515 personal injury cases). The results of the Franklin, Chanin \& Mark study may not include expert fees that were paid by the attorney and included in her own fee. See p. 1686 infra. 
litigation expense second only to the attorney's fee. Indeed, if the attorney is paid by contingent fee, ${ }^{3}$ remuneration of experts may be the litigant's largest out-of-pocket expense. ${ }^{ \pm}$The necessity of paying an expert's fee may therefore deny many potential litigants the opportunity to assert their claims in court. ${ }^{5}$ Yet the ability to pay an expert's fee is unrelated to the merits of the claim or to the importance of the issues at stake. ${ }^{\circ}$

If compensation of an expert witness were contingent on the outcome of the case, her fee would not constitute as substantial a barrier to litigation. The contingent fee option, however, is generally unavailable. The Code of Professional Responsibility (CPR) ${ }^{7}$ and the

3. A fee is contingent if its payment is conditioned on occurrence of the event that is the object of the services performed. Attorney contingent fees are usually conditioned on recovery of a monetary judgment or settlement by the hiring litigant. The fee is usually a percentage of the recovery, although the parties may agree to a contingent lump sum or an hourly rate instead. For a definitive treatment of attorney contingent fees, see $F$. Mackinnon, Contingent Fees for Legal Services (1964). This Note assumes that plaintiff' attorneys are compensated on a percentage contingent fee.

4. See, e.g., Burgess v. Williamson, 506 F.2d 870, 879 (5th Cir. 1975) $(\$ 43,000$ attorney fees; $\$ 20,000$ accountant); J. BrenNAN, supra note 2, at $11,73-76,83$ (two case studies showing expert witness fees for consultation and testimony to be plaintiff's second largest litigation expense after attorney fees). Expert fees are generally much larger than court costs such as filing fees. Compare Public Provision, supra note 1 , at app. C (cxamples of court fees) with note 2 supra (listing expert fees).

The cost of the plaintiff's time in prosecuting her case is likely to be small compared to attorncy or expert witness fees. See J. BRENNAN, supra note 2, at 11, 73-76 (S72 plaintiff's time compared to $\$ 565$ attorney fee and $\$ 250$ expert fee in one illustrative case; \$23I plaintiff's time compared to $\$ 2110$ attorney fee and $\$ 975$ expert fee for examinations, consultations, and testimony in another; 1966 data); cf. A. Conard, J. Morgan, R. Pritt, C. Voltz \& R. Bombaugh, Automobile Accident Costs and Payments 52, 193 fig. 6-10 (1964) (lawyers' fees major component of tort claim collection expenses) [hereinafter cited as A. Conarn].

5. A distinguished commentator has complained:

In order to prove his claim, or to defend against one, a [litigant] . . may need the services of an engineer, or a chemist, or an expert accountant, to make an extensiveand therefore expensive-investigation. Without the evidence which such an investigation would reveal, a man is often bound to be defeated ... . For want of money, .. many a suit has been lost, many a meritorious claim or defense has never even been asserted.

J. Frank, Courts on Trial 94 (1950).

6. Cf. B. Christensen, Lawyers for People of Moderate Means 143-44 (1970) (lawyer unavailability to moderate income claimants unrelated to claim merits); Spector, Financing the Courts Through Fees: Incentives and Equity in Civil Litigation, 58 Judicature 330,334 (1975) (court costs and fees create barriers unrelated to merits).

7. The $A B A$ Code of Professional Responsibility states:

A lawyer shall not pay, offer to pay, or acquiesce in the payment of compensation to a witness contingent upon the content of his testimony or the outcome of the case.

But a lawyer may advance, guarantee, or acquiesce in the payment of:

(1) Expenses reasonably incurred by a witness in attending or testifying.

(2) Reasonable compensation to a witness for his loss of time in attending or testifying.

(3) A reasonable fee for the professional services of an expert witness.

ABA Code of Profession.t. Responsibility, Disciplinary Rule [DR] 7-109(C) (footnote 


\section{common law of legal ethics ${ }^{8}$ prohibit such fees, as do the codes of several expert professions." Although experts receive de facto con-}

omitted) [hereinafter cited as CPR]. See id. Ethical Consideration [EC] 7-28 ("[I]n no event should a lawyer pay or agree to pay a contingent fee to any witness.") Disciplinary Rules are mandatory and prohibitive; their violation subjects the attorney to disciplinary action. Ethical Considerations are merely aspirational. Preamble, id. Although the CPR prohibition applies directly only to attorneys, it acts to prohibit explicit contingent fee arrangements with experts altogether. Because the attorney is likely to have the most extensive contact with the expert and to arrange compensation, see note 44 infra, her acquiesence to the fee arrangement is a practical necessity in almost all cases.

A federal district court found this prohibition of expert contingent fees violative of the Fourteenth Amendment. Person v. Association of Bar, 414 F. Supp. 144 (E.D.N.Y. 1976), rev'd, 554 F.2d 534 (2d Cir. 1977); 81 Dick. L. REv. 655 (1977). The district court found that the prohibition violated the right of access to the courts articulated by the Supreme Court in Boddie v. Connecticut, 401 U.S. $371,376-79$ (1971). 414 F. Supp. at 145. The Second Circuit reversed, noting that the plaintiff below had not been completely denied access to litigation even though the prohibition could discourage "litigation of difficult and complex matters." Person v. Association of Bar, 554 F.2d at 537-38. The Second Circuit held that the fear of perjured expert testimony provided a sufficiently rational basis for the prohibition to withstand constitutional challenge. Id. at 538. The court did acknowledge policy arguments in favor of removal of the prohibition, but felt that such factors should be considered in a legislative rather than in a judicial forum. Id. at 539. It is to such policy arguments that this Note is addressed.

8. The common law of legal ethics is the body of case law regulating the professional activities of attorneys prior to or without reference to codification of legal ethics in the CPR and its predecessor, the $A B A$ Canons of Professional Ethics. For judicial condemnation of expert contigent fecs, see, e.g., In re Imperatori, 152 App. Div. 86, 136 N.Y.S. 675 (1912); In re Schapiro, 144 App. Div. 1, 10-11, 128 N.Y.S. 852, 859-60 (1911). Cf. I STITE Bar of Oklahoma, The Advisory Opinions of the Board of Governors, Nos. 69, 103 (1936); H. DRINkER, Legal Ethics 86 (1953) (citing cases decided by state bar association disciplinary committees prior to passage of CPR); Opinions by Committee on Legal Ethics, 3 A.B.A. Bull., Jan. 19, 1928, opinion 45 at 24.

There have been cases, however, in which the propriety of expert contingent fces has been upheld. Marine Midland Trust Co. v. Forty Wall St. Corp., 13 App. Div.2d 118, 125-26, 213 N.Y.S.2d 689, 696-97 (1961), aff'd in part mem., 11 N.Y.2d 679, I80 N.E.2d 909, 225 N.Y.S.2d 755 (1962). The lower court in Person v. Association of Bar, 414 F. Supp. 144, 146 (E.D.N.Y. 1976), upheld the propriety of expert contingent fees, but was reversed on appeal, $554 \mathrm{~F} .2 \mathrm{~d} 534$ (2d Cir. 1977). See note 11 infra (citing cases implicitly approving contingent fees).

9. See, e.g., American Med. Ass'n [AMA], Opinions and Reports of the Judicial Council 56-57 (1960) (interpreting $\$ 7$ of AMA Principles of Medical Ethics); N.tTionaL Interprofessional Code for Physicians and Atrorneys, reprinted in 45 A.B.A.J. 33 (1959); American Society of Questioned Document Examiners Code of Ethics ff 7, reprinted in 40 A.B.A.J. 690, 691 (1954). But of. American Institute of Certified Public Accountants, Code of Professional Ethics rule 302, at 20 (1975) (contingent fees prohibited with exception: "Fees are not regarded as being contingent if fixed by courts . . . or, in tax matters, if determined based on the results of judicial proceedings . . . .") Removing from the $A B A$ Code of Professional Responsibility the prohibition on expert contingent fees set in reasonable amount by the trial comt, as recommended at p. 1698 infra, would not necessarily free all experts interested in contingent fees to enter such contracts. It seems reasonable to assume, howerer, that other professions would follow modification of the legal profession's prohibition, at least in the area of forensic scrvices for judicially supervised fees.

Prohibition of expert contingent fees in litigation is aimed primarily at preservation of the integrity of expert testimony in court. See Preamble, National InterprofessionaL Code for Phisicians and Attorneys, 45 A.B.A.J. 33 (1959) (goals of Code include facilitation of administration of justice); Aims and Ideals, American Societr of Ques- 
tingent compensation in some situations, ${ }^{10}$ explicit contracts for expert contingent fees are not enforceable in most jurisdictions. ${ }^{11}$

The proscription of contingent fees for expert witnesses is based upon the judgment that such fees, by intensifying the expert's interest in the outcome of the case, would undermine the reliability of the expert's testimony. But this judgment does not withstand careful theoretical scrutiny. This Note argues that contingent fees set in reasonable amount by the trial court are consistent with basic goals of

tioned Document Examiners Code of Ethics, 40 A.B.A.J. 690 (1954) (purpose of Code "the promotion of justice through the discovery and proof of the facts"); p. 1697 \& note 85 infra. But see AMA, OpINIONS ANd Reports of THE Judicial Council 56-57 (1960) (prohibition aimed not only at preventing undue advocacy by physician, but also at "uphold[ing] the dignity and honor of [the medical] profession"). If the legal profession determined that contingent fees did not substantially threaten the integrity of expert testimony or that the threat was outweighed by the benefits of such arrangements to the adjudicatory system, other professional groups would likely defer to that assessment as within the competence of the legal profession. To the extent that the other professions' prohibitions stem from more persistent prejudices concerning proper professional conduct, modification of the legal profession's prohibition is less likely to prompt renunciation of those prohibitions.

10. Expert compensation is de facto contingent when it depends upon the success of the litigation even though the fee contract is explicitly noncontingent. Compare note 3 supra. A de facto contingency can occur in two circumstances. First, expert compensation is de facto contingent if the litigant's practical ability to pay depends on her success at trial. See Person v. Association of Bar, 414 F. Supp. 144, 146 (E.D.N.Y. 1976), rev'd on other grounds, 554 F.2d 534 (2d Cir. 1977); Bomar, The Compensation of Expert Witnesses, 2 Law \& Contemp. Prob. 510, 521 (1935). Second, a de facto contingency arises when an expert's continuing employment with a litigant or her attorney depends upon success in the current case. A physician retained by an insurance company to testify in personal injury cases is an example. See Schuler v. St. Louis Can Co., 322 Mo. 765, 775, 18 S.W.2d 42, 46 (1929); Brief for Plaintiff, supra note 2, at 21-23.

Expert contingent compensation is currently tolerated when the expert's fee is awarded by the court to a successful plaintiff along with attorney fees. See, e.g., Welsch v. Likins, 68 F.R.D. 589, 596-97 (D. Minn. 1975) (civil rights action against state facilities for mentally retarded); Marine Midland Trust Co. v. Forty Wall St. Corp., 13 App. Div. 2d 118, 124-25, 213 N.Y.S.2d 689, 695-96 (1961), aff'd in part mem., 11 N.Y.2d 679, 180 N.E.2d 909,225 N.Y.S.2d 755 (1962) (corporate reorganization suit; explicit recognition of de facto contingency). Under these circumstances, the expert's explicit fee contract might be either contingent or noncontingent. It is likely that the fee contract would be explicitly contingent under statutes specifically authorizing award of expert fees. See, e.g., Glean Air Amendments of 1970, $\$ 12(a), 42$ U.S.C. $\$ 1857 h-2$ (d) (1970) (authorizing court award of reasonable attorney and expert witness fees); Consumer Products Safety Commission Improvements Act of 1976, $\$ 10(d), 15$ U.S.C.A. $\$ 2073$ (West Cum. Supp. 1977) (same).

11. Such contracts are considered violative of public policy. See, e.g., Von Kesler v. Baker, 131 Cal. App. 654, 658-59, 21 P.2d 1017, 1019 (1933); Sherman v. Burton, 165 Mich. 293, 296-97, 130 N.W. 667, 668 (1911); 6A A. Corbin, Contracts $\$ 1430$, at 379-80 (2d ed. 1962); 14 S. Williston, Contracts $\$ 1716$, at 879.80 (3d ed. W. Jaeger 1972).

In upholding the enforceability of contracts for contingent expert compensation, however, a few cases have implicitly recognized the validity of such arrangements. E.g., Osguthorpe v. Anschutz Land \& Livestock Co., 456 F.2d 996, 1005-06 (10th Cir. 1972) (contingency emphasized in dissenting opinion); Ferroline Corp. v. General Aniline \&: Film Corp., 207 F.2d 912, 916 (7th Cir. 1953); Barnes v. Boatmen's Nat'l Bank, 348 Mo. 1032, 1041, 156 S.W.2d 597, 602 (1941). 
the civil adjudicatory system. ${ }^{12}$ The Note demonstrates that the traditional expectation that contingent fees for experts would degrade testimonial reliability beyond present practices is exaggerated. It establishes that the threat of effective impeachment of the contingent fee expert would tend to limit use of this option to cases where access to litigation would be impossible without it. Finally, using an economic analysis the Note demonstrates that the contingent fee option would improve access to litigation and would increase the number of prejudgment settlements without encouraging litigants to bring frivolous actions.

\section{Analytical Framework}

This Note will assess the expert contingent fee by comparing it with alternative methods of compensation. The alternative methods include plaintiff-paid expert fees, attorney-advanced expert fees, expert fees taxed as costs, and free expert services. The comparison will be limited to plaintiffs' experts ${ }^{13}$ and will be made in light of those goals of the civil adjudicatory system germane to the present discussion. These include equal access to litigation, encouragement of prejudgment settlement, screening of frivolous suits, and maintenance of testimonial reliability. ${ }^{14}$ Three of these four goals derive from the

12. As used in this Note, civil litigation denotes the entire court-oriented process for resolution of private disputes or disputes with government in noncriminal contexts. The process begins with the complaining party's first contact with an attorney, continues through pretrial settlement negotiations and trial preparation, and may continue on to judgment after trial. Excluded from consideration here are criminal and quasi-criminal litigation, such as that centering on civil commitment. In the context of contingent expert compensation, criminal and civil litigation are distinguishable on two grounds. First, policy considerations in criminal litigation have led to a prohibition of all contingent fees, including attorney contingent fees. See Peyton v. Margiotti, $398 \mathrm{~Pa} .86$, 90, 156 A.2d 865, 867 (1959); CPR, supra note 7, at EC 2-20, DR 2-106(C). Second, contingent fees are unlikely in criminal and civil commitment cases since such cases do not provide the litigant with a recovery to which the attorney or expert can look for her fee. See F. Mackinon, supra note 3 , at 52 (discussing attorney fees).

13. Although the contingent fee might be used by either party to a lawsuit, experience with attorney compensation indicates that the contingent option is generally relevant only to plaintiffs seeking a monetary award from which the fee can be paid. See F. MAckinwon, supra note 3 , at $4,25-28$. In condemnation proceedings, however, the defendant seeks an increase in her compensation from the plaintiff, and thereby creates a res from which a successful defendant could pay a contingent fee attorney or valuation expert. See id. at 28 (attorney contingent fees by condemnation defendants). In spite of that exception, this Note will discuss the expert contingent fee as if it were an option for plaintiffs only.

14. These goals cannot be ranked in terms of their relative importance. To establish that an expert compensation option should be added to those options currently in use, it is sufficient to show either that such a change would serve at least one of the goals described above without disserving any of the others or that one or more of the goals is clearly served by the change, while disservice to other goals is insubstantial. This Note takes the latter approach. 
fundamental purpose of the civil adjudicatory system-the resolution of disputes. ${ }^{15}$ Maximization of access ${ }^{16}$ makes formal dispute resolution available to a larger part of the population. Encouragement of settlement ${ }^{17}$ and screening of frivolous suits ${ }^{18}$ aid in the conservation of judicial resources. The fourth goal, maintenance of testimonial reliability, ${ }^{19}$ is particularly important for the present discussion, because it is the primary justification for prohibiting expert contingent fees. ${ }^{20}$

\section{A. Present Systems of Compensating Advocate Experts}

There are two common methods of compensating experts who are selected and employed by the parties. The first is direct payment by the litigant. ${ }^{21}$ Unless payment is required in advance, the expert

15. See, e.g., Vecki v. Sorensen, 171 Cal. App. 2d 390, 393, 340 P.2d 1020, 1021 (1959) (dictum) (Tobriner, J.) ("[C]ourts exist primarily to afford a forum for the settlement of litigable matters between disputing parties."); J. FRANK, supra note 5, at 7; Morgan, The Evolving Concept of Professional Responsibility, 90 HARv. L. REv. 702, 705 (1977); cf. E. Hoeber, The Law of Primitive Mai $275-76$ (1954), reprinted in R. Schwartz \& J. SKolNick, SocictY AND the Legal. ORder 17 (1970) (dispute resolution one of four essential functions of law).

16. See, e.g., Brickman, Of Arterial Passageways Through the Legal Process: The Right of Universal Access to Courts and Lawyering Services, 48 N.Y.U.L. REv. 595 (1973); Goodpaster, The Integration of Equal Protection, Due Process Standards, and the Indigenls' Right of Free Access to the Courts, 56 Iows L. REv. 223 (1970); Michelman, The Supreme Court and Litigation Access Fees: The Right to Protect One's RightsPart II, 1974 Duke L.J. 527; Note, A First Amendment Right of Access to the Courts for Indigents, 82 Y.ALE L.J. 1055 (1973). Access to civil litigation means practical ability to invoke all stages of the adjudicatory process, even though few plaintiffs will continue beyond the settlement stage.

17. E.g., Williams v. First Nat'l Bank, 216 U.S. 582, 595 (1910); Pfizer, Inc. v. Lord, 456 F.2d 532, 543 (8th Cir. 1972); Harding v. Will, 81 Wash. 2d 132, 138, 500 P.2d 91, 96 (1972); see F. MacKinnon, supra note 3 , at 75 . Settlement is discussed further at pp. 1705-11 infra.

18. H. Ross, SetTled Out of Court 4 (1970); Goodpaster, supra note 16, at 256-57; Michclman, supra note 16, at 558-59; Posner, An Economic Approach to Legal Procedure and Judicial Administration, 2 J. LeGsL STud. 399, 417-18 (1973). Frivolous suits are discussed further at pp. 1711-13 infra.

19. See J. Fraxk, supra note 5, at 14-16; J. Wigmore, A Student's Textbook of the L.Aw of Evidence \$ 1, at 5 (1935); cf. M. Freedman, Lawyers' Ethics in an Adversary SYSTEM $2-4$ (1975) (search for truth "a basic value" in adversary trial).

20. See Sherman v. Burton, 165 Mich. 293, 296-97, 130 N.W. 667, 668 (1911); Marine Midland Trust Co. v. Forty Wall St. Corp., 13 App. Div. 2d 118, 131-32, 213 N.Y.S.2d 689, $701-02$ (1961), aff'd in part mem., 11 N.Y.2d 679, I80 N.E.2d 909, 225 N.Y.S.2d 755 (1962) (dissenting opinion); CPR, supra note 7, at EC 7-28.

21. See Gair, supra note 1 , at $\$ 25$ (expert's compensation is primarily matter of concern to client and expert); Bomar, supra note 10, at 517. Although the litigant contracts directly for the expert's services, her attorney is likely to act as intermediary. Public Provision, supra note 1, at 12-13; cf. F. MAcKinion, supra note 3, at 196-97 (general control over details of litigation by attorney); D. RosenrHaL, supra note 2, at 32 (same).

A contract for expert litigation services and testimony for a fee is enforceable as an cmployment contract. Osguthorpe v. Anschutz Land \& Livestock Co., 456 F.2d 996, 1002-04 (10th Cir. 1972); Hartley v. Alabama Nat'l Bank, 247 Ala. 651, 654, 25 So. 2d 680, 681-82 (1946). 
bears some risk that the litigant will default. The second common method is the attorney-advanced expert fee.22 The attorney either advances the fee or warrants that it will be paid at the end of the litigation. In either case the attorney risks the litigant's eventual inability to pay the expert's fee. Attorneys paid on a contingent basis are more likely to advance expert fees. ${ }^{23}$

\section{B. Compensation of Court-Appointed Experts}

Experts can be selected and employed by the court, rather than by the parties, to provide expert evidence presumably untainted by partisan associations. The court-appointed expert's fee can be paid out of public funds ${ }^{24}$ or can be taxed by the court to one of the parties. ${ }^{25}$ Provisions for court appointment have been tested by experimental project, ${ }^{26}$ and have been enacted in court rules, ${ }^{27}$ state statutes, ${ }^{28}$ and

22. The attorney-advanced expert fee is commonly used by indigent personal injury plaintiffs. Institute of Judiclal Administration, Contingent fees in Personal Injury and Wrongful Death acrions in the United States 2 (1957) [hereinafter cited as Contingent Fees in Personal Injury]; F. Mackinnon, supra note 3, at 69; cf. J. Cardin, LAWYERS ON THEIR OWN 74, 79-80, 82 (1962) (contingent fee attorneys advance or guarantee expenses of litigation).

23. See F. MAcKinnon, supra note 3 , at $67-69$, 206. The attorney-advanced expert fee does not violate legal ethics. See CPR, supra note 7, at EC 5-8, DR 7-109(C); H. DriNKER, supra note 8 , at 178 .

If the attorney takes a percentage, say $30 \%$, of the net recovery after expenses such as expert fees, she in effect bears $30 \%$ of those expenses. If, on the other hand, the attorney's contingent fee is calculated on the basis of plaintiff's gross recovery, the plaintiff bears the full weight of costs and expenses, including the expert fee. See, e.g., RuLES OF Practice, N.Y. APP. Div., Ist DeP'T $\$$ 603.7(e)(3); D. Rosenthal, supra note 2, at 108.

24. See, e.g., Cal. Evid. Code $\$ 731$ (b) (West 1966); Ill. Sup. CT. R. 215(d)(5); N.Y. \& Bronx Counties Sup. Cr. R. $\$ 660.11(\mathrm{l})$.

25. See, e.g., Fed. R. Evid. 706(b); CaL. Evid. Code \$ 731(c) (West 1966); R.I. Gen. Laws \$ 9-17-19 (Supp. 1976). Cf. S.D. Complled Laws ANN. \$ 19-6-10 (1967) (requiring equal division of appointed expert's fees between parties).

The rules employed by the court in taxing costs would determine which party pays the fee. Normally court costs are assigned to the loser. Kansas City S. Ry. v. Guardian Trust Co., 281 U.S. 1, 9 (1930); D. DoBBS, HANDBOOK oN THE LAw OF Remedies $\$ 3.8$, at 193-94 (1973); C. McCoRmick, HandBooK on THE LAw of Damages $\$ 60$ (1935). Taxable court costs usually include relatively insignificant charges for official courtroom services such as clerk fees, docket fees, and jury expenses. Alternatively, expert fees could be assessed against both parties in a proportion set by the court. See Fed. R. Evid. 706(b). Several states have adopted either the federal rule or the substantially identical uniform rule. UNiform Rule of Evidence 706; ME. R. Evid. 706; Neb. Rev. Stat. \$ 27-706 (1975); N.M. Stat. Ann. \$ 20-4-706 (Supp. 1975); Wis. Star. ANn. \$ 907.06 (1975).

26. From 1952 to 1954 , court appointment of medical experts in personal injury litigation was instituted in a foundation-funded experiment in New York City. Speciat Comm. of Ass'N of Bar of City of New York, Impartial Mledical Testmony (1956) [hereinafter cited as Impartial Medical Testimony]. The system used in that experimental project has been enacted in N.Y. \& Brovx Counties SUP. CT. R. $\$$ 660.11(1).

27. See, e.g., Ill. Sup. Cr. R. 215(d); N.Y. \& Bronx Counties Sur. CT. R. $\$ 660.11(l) ; 3$ J. Weinstein \& M. Berger, Weinstein's Evidence f 706[01], at 706-08 n.5 (1975) (citing local federal district court rules) [hereinafter cited as WEINSTEIN \& BERGER].

28. See, e.g., CAL. Evid. Code $\$ \$ 730-733$ (West 1966); R.I. GeN. LAws \$ 9-17-19 (Supp. 1976); S.D. CoMpiled LAws ANN. \$ 19-6-1 (1967). 
the Federal Rules of Evidence..$^{29}$ These schemes contemplate the selection of nonpartisan experts by the court, either from an approved list of qualified experts ${ }^{30}$ or by agreement of the parties. ${ }^{31}$ But court appointment of nonpartisan experts seldom prevents parties from employing additional experts..$^{32}$ Moreover, court appointment has been infrequent in those jurisdictions in which it is permitted. ${ }^{33}$

\section{Other Expert Compensation Options}

Fees of experts selected by the parties may be taxed as costs of the litigation..$^{3 \pm}$ The court could tax the fees against one party or it could apportion the fees between the parties. Taxation of expert fees as costs of litigation would put each litigant at risk of having to pay all or part of the fees for both sides' experts.

Expert fees may also be paid by organizations such as legal aid or group legal services. As with government funding of court-appointed experts, payment of experts by an institutional funding source removes the burden of expert fees from the litigant. But to the extent that the

29. FED. R. EvID, 706. Rule 706(a) allows court appointment sua sponte or on the motion of either party. The court may select the expert to be appointed or may accept an expert agreed upon by the parties. Id.

30. See, e.g., Ill. Sup. CT. R. $21: 5(\mathrm{~d})(1)$; N.Y. \& Browx Countirs Sup. CT. R. $\$ 660.11(1)$.

31. See, e.g., S.D. Compiled LAws ANn. § 19-6.3 (1967); Model Code of Evidence rule 403(b) (1942); UNIForM EXPERT Testimony Act $\$ 4$ (1937). FED. R. Evid. 706(a) allows expert selection either by the court or by concurrence of the parties.

32. See, e.g., Fed. R. Evid. 706(d); Cal. Evid. Code $\S 733$ (West 1966); S.D. Compiled Liws ANN. \$ 19.6.8 (1967); Impartial Medicil Testimony, supra note 26, at 15, 17; 3 Weinstein \& Berger, supra note 27, If 706[02], at 706-15 to 706-16 (quoting J. Wigmore).

Court-appointed experts cannot provide all the expert services required by the parties. In addition to giving testimony at trial, experts perform important settlement and trial preparation functions. For example, expert advice may be required for the attorney's initial evaluation of the case, for witing technical reports to be used in settlement negotiations, and for preparing the attorney for deposition and trial cross-examination of opposing experts. S. Speiser \& P. Rheingold, Negligence Case Techniques $\$ 8.2$ (1969); Bomar, supra note 10, at 510-11; Gair, supra note 1, at $\$ \$ 6,11$.

33. See p. 1696 \& note 78 infra.

34. This option would tax the expenses of litigation-primarily attorney and expert witness fees-in much the same manner as court costs are currently taxed, see note 25 supra. See LA. Rev. ST.AT. ANN. \$ 13.3666 (West 1968) (fees of experts called to testify taxed as costs against losing party in amounts set by court as reasonable fees); Note, Awarding Attorney and Expert Wilness Fees in Environmental Litigation, 58 CoRNELL L. REv. 1222, 1222-23 (1973).

The "American rule" that each party is responsible for her own litigation expensesparticularly attorney fees-has been debated extensively. See, e.g., Ehrenzweig, Reimburseinent of Counsel Fees and the Great Society, 54 CALIF. L. Rev. 792 (1966); Kuenzel, The Attorney's Fee: Why Not a Cost of Litigation?, 49 Iowa L. Rev. 75 (1963); Mause, Winner Takes All: A Re-examination of the Indemnity System, 55 IowA L. REv. 26 (1969); Comment, Court Awarded Attorney's Fees and Equal Access to the Courts, 122 U. PA. L. REv. 636 (1974). This mode of allocating litigation expenses is usually contrasted to the "English rule" that the losing party bears both sides' litigation expenses. See, e.g., Kuenzel, supra at 80-8I; Comment, supra at 637 n.2. 
institutional funding source has limited financial resources, it may suffer from disabilities similar to those of an individual litigant with a limited budget. ${ }^{3 \overline{3}}$

\section{Contingent Fees for Experts}

A contingent fee for an expert witness could be calculated as a percentage of the litigant's recovery in the case ${ }^{36}$ or as a flat hourly fee available only if the claim is successful. It could also be awarded by the court in a reasonable amount from the successful litigant's recovery. ${ }^{37}$ The contingent fee option is normally relevant only in cases that seek a damage award from which the fee can be paid or in cases in which the court is empowered to award fees and expenses to the successful plaintiff. ${ }^{38}$

\section{Testimonial Reliability and Expert Compensation}

The purpose of the expert witness is to present specialized information and to assist the factfinder in drawing appropriate inferences from

35. For budget constraints faced by an individual litigant, sec pp. 1699-1701 infra. A legal aid office may face analogous budget constraints, especially if the office limits the expenditures allowed for any single case. See Purdic Provision, supra note 1, at 3; National Legal Aid \& Defender Ass's, Handbook of Standakds 5 (1970) [hereinafter cited as NLADA]; Silverstein, Eligibility for Free Legal Services in Civil Cases, 44 J. URB. I. 549,551 (1967).

In any event, few litigants have this option. Legal aid is generally not available for any case a contingent fee attorney would take. $I d$. at 552 . Nor is it available for clients not meeting strict eligibility requirements. NLADA, sitpra at 3-4; Silverstein, supra at 555-68.

Discovery of facts and opinions held by an opponent's expert might seem to be another option for providing expert services to a party unable to hire her own expert. FED. R. Crv. P. 26(b)(4) provides for discovery of facts and opinions held by an opposing expert expected to testify or employed for trial preparation, subject to limitation by the court and reimbursement to the expert or employing party. Discovery, however, is likely to occur too late to, meet the litigant's trial preparation requirements. Notes of Advisory Comm. on 1970 Amendment to Rules, FED. R. Civ. P. 26(b)(4), reprinted in 28 U.S.C. app. at 7780 (1970); Friedenthal, Discovery and Use of an Adverse Party's Expert Information, 14 Stan. L. REv. 455, $487-88$ (1962). But see Long, Discovery and Experts Under the Federal Rules of Civil Procedure, 38 F.R.D. 111, 153-54 (1966) (proposing limitations on discovery of experts to prevent its substitution for preparation with one's own expert).

36. Cf. F. MACKinnon, supra note 3, at $65-66$ (percentage contingent fees for attorneys); ContiNgent Fefs ix Personal. Injury, supra note 22, at app. II (same). Different types of percentage contingent fees are discussed at pp. 1707-08 \& note 127 infra.

37. The court's calculations would be similar to calculations of reasonable attorney fees in, for example, stockholder derivative and antitrust actions. See, e.s., Angoff v. Goldfine, 270 F.2d 185, 188-89 (1st Cir. 1959) (listing factors in calculation of reasonable fees for attorneys and accountants); Marine Midland Trust Co. v. Forty Wall St. Corp., 13 App. Div, 2d 118, 126-27, 213 N.Y.S.2d 689, 696-97 (1961), aff'd. in part mem., 11 N.Y.2d 679, 180 N.E.2d 909, 225 N.Y.S.2d 775 (1962) (same; for appraisers serving as expert witnesses).

38. See F. Mackinion, supra note 3, at 18-24. Unless otherwise noted, expert contingent fees are assumed to be calculated as a percentage of recovery. 
that information. ${ }^{39}$ Because of the technical nature of some evidence, the factfinder may be wholly dependent upon expert guidance. Biased expert testimony may leave the factfinder unable to resolve intelligently the technical issues presented at trial. ${ }^{40}$ To determine the effect of the contingent fee option on testimonial reliability, it is necessary to examine both the sources of testimonial bias and the safeguards against it.

\section{A. Sources of Bias in Expert Testimony}

Expert evidence is biased when it deviates substantially from the consensus of experts in the field or, if there is no consensus, when it fails fairly to present reasonable alternative positions. ${ }^{41}$ Bias defined in this manner may arise from the process of expert selection. This will be termed "selection bias." It may also arise from the conscious or unconscious modification of an expert's opinion to coincide more closely with her client's needs. This will be termed "modification bias." 12

39. United States v. Jackson, 425 F.2d 574, 577 (D.C. Cir. 1970) (jury could "receive appreciable help" from expert pickpocket); Spitzer v. Stichman, 278 F.2d 402, 409 (2d Cir. 1960) (expert's special knowledge, experience, and judgment "helpful to the court in determining the issue"); Angel v. Rand Express Lines, Inc., 66 N.J. Super. 77, 85, 168 A.2d 423, 427 (1961) (expert testimony justified by "relative helplessness of the average juror in dealing with a subject not of common knowledge"); $7 \mathrm{~J}$. Wigmore, supra note 1 , at $\$ 1923$.

40. The general concern is that, because of its dependence on biased experts for unfamiliar information and inferences, the jury may fail to reach an accurate result; that is, a result conforming to well-founded expert opinion. See Impartial Medical TestrmoNy, supra note 26, at 3, 6-8; SUncomm. on Patents, Trademarks, and Copyrichts of Sen.ate Comm. on Judiciary, 85th Conc., Ist Sess., The Role of the Court Expert in Patent Litig.tion 1.4 (Comm. Print 1958) (study prepared by L. Whinery) [hereinafter cited as L. WhINERY]; $2 \mathrm{~J}$. WIGMORE, supra note 1 , at $\$ 563(2)$; Van Dusen, The Impartial Mredical Expert System: The Judicial Point of View, 34 TEMr. L.Q. 386, 387-88 (1961).

The problems of reliability of expert evidence and of normal factual evidence differ in two respects. The fact witness reports only perceptions within the jury's normal range of experience. Her inferences from those perceptions are generally inadmissible. C. McConMICK, LAW of Evidence $\$ 10$ (2d ed. E. Cleary 1972). But see Fed. R. Evid. 701 (permitting lay opinion evidence that is rationally based on perception and helpful to factfinder). The expert, on the other hand, supplies complex technical inferences to the jury in the form of opinion testimony. It is generally felt that expert opinions and inferences are more susceptible to effective modification or manipulation to mislead the lay factfinder than are reports of perceptions by lay witnesses. 3 WEINSTEIN \& BERGER, supra note $27, \Upsilon 706[01]$, at 706-07 to 706-08. Contra, 2 J. Wigsore, supra note 1 , at $\$ 563(1)$.

41. There may be two or more acceptable schools of thought among experts in a particular field. In such a situation, an opinion confined to one school of thought may be said to be biased because it deviates from impartial presentation of all acceptable viewpoints.

42. The term "bias" is usually restricted to modification of an individual expert's opinion, termed "modification bias" in the text. See C. McCorMick, supra note 40, at $\$ 40$ (bias includes faror, hostility, self-interest, and corruption); $c f$. $3 \mathrm{~A} \mathrm{~J}$. WIGMoRE, supra note 1 , at $\$ 940$ (Chadbourn rev. 1961) (personal bias, interest, and corruption all varicties of emotional incapacity). 


\section{Selection Bias}

The expert selection process can be a source of testimonial bias if the expert is selected because of her opinion. ${ }^{43}$ Litigants and their attorneys are inclined to select supportive experts to increase their chances of success at trial. ${ }^{44}$ In addition to the attorney's professional incentives $^{4 \bar{s}}$ to select a supportive expert, strong pecuniary incentives exist when counsel fees are contingent on the outcome of the case. The "battle of the experts" is thus an inevitable feature of any adversary adjudicatory system that permits parties to select their own expert witnesses. ${ }^{46}$

Court appointment of expert witnesses can also be a source of expert

43. Jessel, M.R., complained:

[T] he mode in which expert evidence is obtained is such as not to give the fair result of scientific opinion to the Court. A man may go, and does sometimes, to half-adozen experts .... . He takes their honest opinions, he finds three in his favour and three against him; he says to the three in his favour, Will you be kind enough to give evidence? and he pays the three against him their fees and leaves them alone; the other side does the same. It may not be three out of six, it may be three out of fifty.

Thorn v. Worthing Skating Rink Co. (Ch. 1876) (opinion of Jessel, M.R.), quoted in Plimpton v. Spiller, 6 Ch. D. 412 , 415 n.2 (1877). See Notes of Advisory Comm. on Proposed Rules, FED. R. Evid. 706, reprinted in 28 U.S.C. app. at 2343 (Supp. V 1975) (describing "[t]he practice of shopping for experts" as a matter "of deep concern"); Van Dusen, supra note 40 , at 387 (noting that "opposing parties still search until they find experts whose testimony supports their positions"); Yerion, Expert Medical Testimony in Compensation Proceedings, 2 LAw \& Contemp. ProB. 476, 477 (1935) (competent experts likely to hold strong convictions and opinions; party generally will call that expert whose opinions fortify her case).

44. The expert is likely to have more contact with the attorney than with the litigant. The attorney usually exercises effective control over the selection and the use of the expert. See R. KeEton, Trisl Tactics and Methods $\$ \S 2.15,9.8$ (2d ed. 1973) (general discussion for attorneys on selection and use of expert witnesses); Gair, supra note 1, at $\S \S 12,19-24$ (same).

The incentives that may lead the litigant and attorney to select an expert who supports their case may also lead them to select an expert willing to adapt her opinion, or her report of it, to suit the interests of her employers. Commissioner's Prefatory Note, Modec Expert Testimony Act (1937); F. IWellman, The ARt of Cross-Examination 95 (4th ed. 1962); Van Dusen, supra note 40, at 387-88. The litigant and her attorney will not, however, prefer such a witness over an honestly supportive expert, all else being equal. The adaptable expert is likely to be more susceptible to effective impeachment on crossexamination, which reduces her credibility before the factfinder and her value to her employers. R. KEETON, supra, $\$ 9.8$, at 321 (advising attorneys against use of easily impeachable experts); Gair, supra note 1 , at $\$ 23$ (same). See pp. 1697-98 infra.

45. See CPR, supra note 7, at EC 7-1 ("The duty of a lawyer . . is to represent his client zealously within the bounds of the law ...." (footnotes omitted)); id. at EC 7-4 ("The advocate may urge any permissible construction of the law favorable to his client ...."); $i d$. at EC $7-19$ ("[T] he adrocate, by his zealous preparation and presentation of facts and law, enables the tribunal . . . to render impartial judgments." (footnote omitted)); $i d$. at $\mathrm{DR} 7-10(\mathrm{~A})(\mathrm{l})$ (prohibiting attorney from "[failing] to seck the lawful objectives of his client through reasonably available means permitted by law" (footnote omitted)).

46. See L. Whinery, supra note 40, at 2; Levy, Impartial Medical Testimony-Revisited, 34 TEMP. L.Q. 416, 427-28 (1961). Contra, Van Dusen, supra note 40, at 393. 
selection bias. If experts are selected by the judge or are called at random from a list of experts previously approved by some neutral authority, ${ }^{47}$ expert bias will have a random effect on the litigation but will not be eliminated. If the question that requires expert testimony is one on which competent experts in the field differ, then random selection of a supposedly impartial expert may favor that party whose position corresponds to the expert's predilections. ${ }^{48}$

\section{Modification Bias}

In addition to bias arising from the expert selection process, bias may result from an expert's conscious or unconscious modification of her opinion or the report of it to favor the side for which she testifies. This modification bias may occur because the witness identifies with her employers or because she has a pecuniary interest in the outcome of the case.

Experts tend generally to identify with the litigant and attorney they are assisting, especially if their assistance involves a major investment of time or effort. ${ }^{49}$. Identification can cause the expert to make

47. If the expert is selected by the court, no selection criteria are specified. See, e.g., FED. R. Evid. 706(a). A few court appointment schemes provide for establishment of lists of approved experts in certain fields. See, e.g., Impartial Medical Testimony, supra note 26, at 13-14 (medical experts of "extremely high standing" and lacking prominent identification with plaintiffs or defendants selected by local medical society for New York City's impartial medical expert project); Note, The Doctor in Court: Impartial Medical Testimony, 40 S. CAL. L. REv. 728, 730 n.I4 (1967) (same; for Los Angeles court appointment program). Alternatively, experts can be selected for court appointment by agreement of the parties. See p. 1687 \& note 31 supra.

48. 3 WeINSTEIN \& BERGER, supra note 27, I 706[01], at 706-10 to 706-11; Levy, supra note 46, at 419-23; Schuck, Techniques for Proof of Complicated Scientific and Economic Facts, 40 F.R.D. 33, 38-39 (1967). Contra, Griffin, Impartial Medical Testimony: A Trial Lawyer in Favor, 34 TEMP. L.Q. 402, 409-11 (1961). See note 41 supra.

If a court-appointed expert adequately presents the differing viewpoints on the technical question at issue, her testimony will not be biased as defined at p. 1689 supra. Provisions for court appointment do not, however, require such evenhandedness of appointed experts. See, e.g., FED. R. Evid. 706. The testimony of randomly selected experts is biased only with respect to the specific cases in which that testimony is given. The testimony of such experts over time should tend to be unbiased-with differing viewpoints cancelling each other out in the aggregate. The eventual neutrality of aggregated points of view is, unfortunately, quite irrelevant to the individual litigant with a specific claim or defense which depends upon expert testimony.

49. See H. Simon, Administrative Behavior 205 (3d ed. 1976). Simon defines identification: "a person identifies himself with a group when, in making a decision, he evaluates the several alternatives of choice in terms of their consequences for the specified group." Id. at 205 (emphasis omitted). In this context, the "group" with which the expert may identify is the litigant and her attorney. A major investment of time and effort by the expert on the objectives of this group can narrow the focus of her attention and, by so doing, prevent consideration of values and objectives inimical to the group objective. This results in the expert's identifying with the litigating group. See id. at 210-12. Simon's discussion of identification concerns long-term association with large organizations, but analogous influences can be expected from association of a shorter term with 
unconscious alterations in her opinion to support the other participants in pursuit of their common goal-success in the litigation. ${ }^{50}$

Perception of a direct or an indirect interest in the outcome can lead the expert unconsciously to modify her opinion. ${ }^{51}$ This "interest bias" is most likely to arise when the expert has a direct financial interest in the outcome of the case, ${ }^{, 52}$ such as that created by a contingent fee. A similar, but less direct, interest exists if the expert believes that the result of the litigation will affect her economic interests in other cases. Failure in the case at bar, for example, could jeopardize a longstanding relationship with a particular litigant or attorney. ${ }^{53}$ Similarly, failure might diminish the expert's reputation for effective-

a small group such as the litigating team. See Thomas \& Fink, Effects of Group Size, in SMall Groups 525, 532-33 (rev. ed. A. Hare, E. Borgatta \& R. Bales eds. 1966) (studics indicate conformity to group judgment increases significantly as group size increases from one to three; effect of larger group size inconclusive); cf. Bales, The Equilibrium Problem in Small Groups, in id at 444,445, 467-70 (increase in small working group agreement and solidarity over short time periods); Kelman, Compliance, Identification, and Internalization: Three Processes of Attitude Change, in Reidings in Arrmude Chaxge 220 (S. Himmelfarb \& A. Eagly eds. 1974) (identification occurs when influence is accepted in order to establish or maintain satisfying relationship with another person or group).

The strength of an expert's identification with the litigant and attorney will depend upon the amount of time and effort required of her by the working relationship. For examples of the types of services provided by expert witnesses, see note 32 supra. Some experts may develop long-term working relationships with particular attorneys or litigants, see notes 10 supra \& 67 infra, which increase the tendency to identify with their employers' goals in the litigation. The wide variety of experts and questions requiring expert testimony makes it difficult to generalize about experts' relationships with attorneys and litigants, and therefore difficult to generalize about the strength of the identification resulting from those relationships. Cf. note 110 infra (discussing variations in market for expert services).

50. See E. Hartley \& R. Hartley, Fundamentals of Social Psychology 392-93 (1952) (emergence of group goals and group cohesiveness through interaction of members); $H$. Simon, supra note 49, at 198-99 ("[T]he values [of the group] gradually become internalized' and are incorporated into the psychology and attitudes of the individual participant."); L. WhinerY, supra note 40, at 1 (bias attributable to, inter alia, "subtle psychological forces arising" from "prior consultations with the party").

Although identification is not explicitly mentioned in the legal literature on bias, Wigmore's definition of bias implies that identification bias can arise from an employment relationship. See 3A J. Wigmore, supra note 1, at $\$ \$ 945$, 919 (Chadbourn Rev. 1961) (defining testimonial bias as "all varieties of . . . prejudice" for one party or against the other, including that arising from personal relationship). Similarly, McCormick recognizes "favor or friendly feeling toward a party" as a form of bias distinct from pecuniary self-interest but often evidenced by a business or employment relationship. C. McCormick, supra note 40 , at $\$ 40$ (emphasis omitted).

51. "A Doctor," Psychology in Covkt 55-56 (anon. 1933); Bomar, supra note 10, at 522; Van Dusen, stupra note 40 , at 388.

52. C. MCCormick, supra note 40 , at $\$ 40 ; 3 \mathrm{~A}$ J. Wigmore, supra note 1 , at $\$ 966$ (Chadbourn Rev. 1961). See R. KeEToN, supra note 44, at $\$ \$ 3.27,9.8$; note 68 infra (citing cases).

53. See Brief for Plaintiff, supra note 2, at 20-23. For examples of experts involved in longstanding employment relationships with particular litigants or attorneys, see note 67 infra (citing cases). 
ness as a witness, and thus decrease the future market value of her testimony. ${ }^{54}$

\section{B. Safeguards against Expert Testimonial Bias}

Bias in expert evidence can be minimized in four ways: court appointment of experts, use of the qualification process, use of opposing experts, and impeachment during cross-examination.

Court selection and employment of experts precludes expert testimonial bias that arises from selection for opinion and from modification due to identification and interest. Those sources of bias stem largely from the adversarial role of experts selected by the parties..$^{\bar{j}}$ The proponents of impartial selection also argue that the presence of a court-appointed expert moderates the biases of any additional experts hired by the parties.50 The parties' experts may attempt to minimize the appearance of partisan bias by modifying their testimony to correspond more closely with the testimony of the court-appointed expert.

An expert must be qualified by the court before she is allowed to give substantive testimony. The court must determine that the subject matter is appropriate for expert testimony ${ }^{\mathbf{5}}$ and that the particular

54. For a description of the market for expert testimony, see note 110 infra.

Another possibility for modification of an expert's (or any other witness's) testimony is corruption-intentional misreporting of her opinion for a fee. Notes of Advisory Comm. on Proposed Rules, FeD. R. Evid. 706, reprinted in 28 U.S.C. app. at 2343 (Supp. V 1975); Bomar, supra note 10, at 522; Van Dusen, supra note 40, at 387-88. That fee could be either contingent or noncontingent. Person v. Association of Bar, 414 F. Supp. 139, 144 (E.D.N.Y. 1976). Corruption may occur with either type of fee. See C. McCorMIck, supra note 40 , at $\S 40 ; 3 A$ J. Wigmone, supra note 1 , at $\$ \S 956,961$ (Chadbourn rev. 1961). Corrupt misreporting of an expert's opinion could also occur in response to de facto contingency of expert compensation. For examples of de facto contingency, see note 10 supra. Intentional misreporting of an opinion in testimony by either an expert or a lay witness is perjury. State v. Sullivan, 24 N.J. 18, 26-27, 130 A.2d 610, 615, cert. denied, 355 U.S. 840 (1957); Shook \& Fletcher Supply Co. v. City of Nashville, 47 Tenn. App. 339, 350, 338 S.W.2d 237, 241 (1960). The problem of perjury is inherent in all testimony.

55. Impartial Medical Testimony, supra note 26, at 7; C. McCormick, supra note 40 , at $\$ 17$; 2 J. WIgmore, supra note 1 , at $\$ 563$; Bomar, supra note 10 , at 522-23. Court appointment may create its own random selection bias, however, as discussed at pp. $16 \mathfrak{9 0 - 9 1}$ and notes $47-48$ supra.

56. Impartial Medical Testimony, supra note 26, at 5, 27-28; Travis, Impartial Expert Testimony Under the Federal Rules of Evidence: A French Perspective, 8 INT'L LAw. 492, 519-20 (1974).

57. Frye v. United States, 293 F. 1013, 1014 (D.C. Cir. 1923) (scientific principle or discovery on which expert's testimony is based "must be sufficiently established to have gained general acceptance" in field); People v. Forte, 279 N.Y. 204, 206, 18 N.E.2d 31,32 (1938) (must show "scientific recognition" of supposed field of expertise); C. McCorMICK, supra note 40 , at $\$ 13$ ("[O]pinion evidence is not admissible if the court believes that the state of the pertinent art or scientific knowledge does not permit a reasonable opinion to be asserted even by an expert." (footnote omitted)). 
witness possesses sufficient qualifications in her field to testify. ${ }^{58} \mathrm{Al}-$ though qualification is generally within the discretion of the trial judge, ${ }^{59}$ the process of qualification seldom includes a screen for expert bias. ${ }^{60}$ Nevertheless, an expert whose willingness to alter her testimony is apparent may well be disqualified by the trial judge. ${ }^{61}$

The use of opposing partisan experts can provide an important safeguard against the bias of any individual expert. For this safeguard to work, however, the factfinder must be able to assess and balance partisan presentations to eliminate the effects of bias emanating from either side. Whether the factfinder can actually choose between complex inferences in unfamiliar areas of knowledge or experience is uncertain. ${ }^{62}$

In the adversary system, impeachment is the primary defense against partisanship and bias in expert testimony. Counsel may impeach an opposing expert either by cross-examination or by introducing evidence that conflicts with the opposing expert's testimony ${ }^{63}$ Both the technical basis of the testimony ${ }^{64}$ and the expert's objectivity may be called into question. Counsel may attempt to demonstrate selection bias by introducing evidence of the expert's reputation for venality among her professional peers. ${ }^{6.5}$ Impeachment may also be used to demonstrate or to imply modification bias. For example, the expert may be confronted with prior statements of her opinion-in the case at

58. See, e.g., United States v. Baumgarten, 300 F.2d 807, 808 (2d Cir. 1962) (degrce of expertise required for qualification dependent on difficulty of subject matter); Sinz v. Owens, 33 Cal. 2d 749, 753, 205 P.2d 3, 5 (1949) (medical expert in malpractice suit must have "basic educational and professional training" and "practical knowledge" of standard medical practices to qualify); C. McCormick, supra note 40 , at $\S 13 ; 2\}$. Wigmore, supra note 1 , at $\$ 560$.

59. See, e.g., United States v. Baumgarten, 300 F.2d 807, 808 (2d Cir. 1962); C. MICCormick, supra note 40 , at $\$ 13$.

60. Cf. C. McCormick, supra note $40, \$ \S 13,203$, at 491 (list of qualification factors omits bias); $2 \mathrm{~J}$. WIGMORE, supra note 1 , at $\$ 560$ (same).

61. See, e.g., FED. R. Evid. 403 (judge may exclude evidence that might tend to mislead jury). Cf. Tabatchnick v. G.D. Searle \& Co., 67 F.R.D. 49, 55-56 (D.N.J. 1975) (testimony of physician disallowed for tendency to "confuse or mislead" jury); Webb v. Olin Mathieson Chem. Corp., 9 Utah 2d 275, 280, 342 P.2d 1094, 1097 (1959) ("[I]t is of great importance that the court carefully scrutinize [the expert's] qualifications to guard against being led astray by the pseudo learned or charlatan ....")

62. 3 WeINSTEIN \& BERGER, supra note 27, If 706[01], at 706-07 to 706-08; Yerion, supra note 43 , at 476 .

63. C. McCormick, supra note $40, \S 40$, at $81 ; 3 \mathrm{~A}$ J. Wigmore, supra note 1 , at $\$ 943$ (Chadbourn Rev. 1961).

64. Ulm v. Moore-McCormack Lines, 115 F.2d 492, 496 (2d Cir. 1940); 3 A J. Wigmore, supra note 1 , at $\$ 992$ (Chadbourn rev. 1961); see C. McConmick, supra note 40 , at $\$ 16$ (cross-examination on technical basis of expert opinion preferable to use of hypothetical question).

65. Cf. C. McCormick, supra note 40 , at $\$ 44$ (witness's reputation for veracity generally subject to impeachment); $3 \mathrm{~A} \mathrm{~J}$. WiGMoRE, supra note 1 , at $\$ \$ 920,922$ (Chadbourn rev. 1961) (same). 
bar, in prior similar cases, or in publications-that are inconsistent with her current position. ${ }^{\circ 6}$ Identification bias may be suggested to the factfinder by cross-examination aimed at the expert's past or present relationship with the party, including employment either in a professional capacity or as a witness. ${ }^{67}$ Interest bias is also a regular target of cross-examining counsel, who frequently question the expert on the amount, conditions, and timing of her compensation. ${ }^{68}$ In those jurisdictions in which judicial comment on the evidence is permitted, the court may supplement partisan cross-examination by commenting to the jury on the credibility of an expert witness. ${ }^{69}$ Impeachment by any of these techniques is intended to induce the jury to disbelieve the expert's substantive testimony. ${ }^{70}$ It thus serves to minimize the effect of bias in that testimony.

\section{Effects of Expert Compensation Options on Testimonial Reliability}

\section{Noncontingent Advocate Experts}

Incentives to select experts supportive of the litigant's position exist whether the advocate expert is chosen by the litigant or by her attorney. The attorney normally selects the expert for the litigant. ${ }^{71}$ The attorney's incentives to exploit available selection bias derive from her professional responsibility zealously to advocate the client's interests, ${ }^{72}$ from her own contingent fee interest in the litigation, ${ }^{73}$ and from interest in her professional reputation. ${ }^{74}$

66. State ex rel. State Pub. Works Bd. v. Stevenson, 5 Cal. App. 3d 60, 65, 84 Cal. Rptr. 742, 746 (1970); Brooks v. Rochester Ry., 156 N.Y. 244, 250-51, 50 N.E. 945, 946-47 (1898); 3A J. WIGMore, supra note 1 , at $\$ 1041$ (Chadbourn rev. 1961).

67. Scott v. Spanjer Bros., 298 F.2d 928, 931-32 (2d Cir. 1962); Schuler v. St. Louis Can Co., 322 Mo. 765, 773-75, 18 S.W.2d 42, 46 (1929). Cf. Mostyn v. United States, 64 F.2d 145, 146 (D.C. Cir. 1933) (prior employment by defendant's attorney). Contra, Zamsky v. Pittsburgh Pub. Parking Auth., 378 Pa. 38, 39-40, 105 A.2d 335, 336 (1954).

68. West Skokie Drainage Dist. v. Dawson, 243 Ill. 175, 182, 90 N.E. 377, 379-80 (1909); Grutski v. Kline, $352 \mathrm{~Pa}$. 401, 404-07, 43 A.2d 142, 143-44 (1945).

69. See C. McConmick, supra note 40 , at $\$ 8 ; 9 \mathrm{~J}$. Wigmore, supra note 1 , at $\$ \$ 2551$, $2551 \mathrm{a}$.

70. See R. KeEtow, supra note 44 , at $\$ 3.4$; cf. 2 J. Wigmore, supra note 1 , $\S 561$, at 643 (noting the "ample and sure safeguard of cross-examination to reveal witness' real qualifications").

71. See note 44 supra.

72. See note 45 supra.

73. See F. MACKINNoN, supra note 3, at 200-01; Gair, supra note 1, at $\$ 19$. The incentives for biased expert selection in noncontingent advocate selection systems are limited by the cost of searching for and assessing different experts. Cf. Posner, supra note 18, at 430-31 (level of expenditures on litigation limited by incremental value to case of those expenditures).

74. See H. DRINker, supra note 8 , at 99 . 
Modification bias is likely in testimony from noncontingent advocate experts. Identification may arise from the expert's association with the attorney and litigant..$^{75}$ Interest bias may result from de facto contingency even when the partisan expert's compensation is explicitly noncontingent. ${ }^{76}$ Thus both selection and modification biases may arise in testimony from noncontingent advocate experts. ${ }^{77}$

\section{Court-Appointed Experts}

Although court appointment of expert witnesses would reduce bias in expert testimony, the option is infrequently invoked. ${ }^{78}$ Whatever the reasons for this disuse, it is clear that court appointment is at best an untested line of defense for testimonial reliability.

Court-appointed experts usually supplement rather than replace partisan experts. ${ }^{79}$ Litigants and attorneys find some services unavailable from a court-appointed expert. Assisting the attorney in evaluation of the case, aiding in settlement negotiations, and preparing for trial $^{80}$ are services that cannot be performed for parties by the courtappointed expert, both because she is likely to be selected relatively late in the pretrial phase of the litigation ${ }^{81}$ and because such partisan services are inconsistent with her neutral role. She only examines the subject of proposed expert testimony, prepares a technical report on that examination, and testifies at trial. ${ }^{82}$ The court-appointed expert

75. See pp. 1691-92 and notes 49 \& 50 supra.

76. See note 10 supra.

77. The biases of noncontingent advocate cxperts and the consequent tendency of expert evidence to mislead rather than to inform juries have been subjects of extensive critical commentary. See, e.g., Hand, Historical and Practical Considerations Regarding Expert Testimony, 15 HARv. L. REv. 40 (1901); Morgan, Suggested Remedy for Obstructions to Expert Testimony by Rules of Evidence, 10 U. CHI. L. REv. 285, 292-93 (1943); Symposium on the Impartial Medical Expert, 34 TEMP. L.Q. 357 (1961).

78. Notes of Advisory Comm. on Proposed Rules, FED. R. Evid. 706, reprinted in 28 U.S.C. app. at 2343 (Supp. $V^{\prime}$ 1975); 3 WeINSTEIN \& Berger, supra note 27, I 706[01], at 706-09; Note, supra note 47, at 729, 734. By 1970, the New York court appointment program was used in only about 200 cases a year out of an incoming negligence case load of approximately 4,500 cases in the Supreme Court and 76,000 cases in New York City Civil Court. 16 Aomin. Bd. OF Jud. Conf. of State of New York, ANiv. Rep. 292, A58, A79 (1971).

79. See 3 WeINSTEIN \& Berger, supra note 27, 7 706[01], at 706-12; cf. Imp.stial Medical Testimony, supra note 26 , at 15 (judge decides whether to appoint expert after examining reports by both parties' experts).

80. See note 32 supra.

81. See Impartial Medical Testimony, supra note 26, at 15 (appointment order after pretrial conference); 3 WEINSTEIN \& BERGer, supra note 27, if 706[02], at 706.12 to 706.13 (appointment after pretrial conference; characterizing this, however, as "considerably before trial" when compared to appointment at commencement of trial); Note, supra note 47 , at $729-30$ (appointment at pretrial conference).

82. Impartial Medical Testimony, supra note 26, at 17-19; see 3 WVinstein \& Berger, supra note 27, If 706[02], at 706-12 to 706-13, 706-20 (preparation of report of expert's findings, testimony at deposition, testimony at trial). 
may thus demonstrate less bias herself and may even moderate the biases of the parties' experts, but her appointment will not eliminate bias in the presentation of expert evidence to the factfinder. ${ }^{33}$

\section{Contingent Fee Experts}

Contingent fee experts are likely to exhibit the selection and modification biases of noncontingent advocate experts. In addition, the contingent fee gives the expert a direct interest in the outcome of the litigation. That interest may induce her to augment normal partisan selection bias with her own screening of cases. She would select cases in which her opinion corresponds with that most supportive of the litigant's claim..$^{84}$ The contingent fee may also induce modification bias; the expert's direct pecuniary interest in the outcome might lead to modification of her opinion. ${ }^{8 s}$ Moreover, the expert's identification with the party may increase under the contingent fee if the expert's direct interest in the outcome of the litigation encourages closer association with the attorney and litigant in assessing and preparing the case. ${ }^{86}$ It seems probable that, absent any countervailing influences, the contingent fee would increase selection bias and modification bias over other advocate expert systems.

The tendency of the contingent fee to increase partisan bias can be limited, however, by means of the adversarial impeachment process and judicial scrutiny of contingent fees. The expert's contingent fee arrangement with a party would be a tempting target for impeachment. The suggestion of biased testimony could easily be reinforced by opposing counsel. ${ }^{87}$ Effective impeachment would reduce the expert's usefulness in supporting the litigant's claim, and thus would reduce the probability of a successful judgment. The litigant and her

83. See L. Whineri, supra note 40, at 4-5; cf. Impartial Medical Testimony, supra note 26, at 31 (continued existence of "honest difference of opinion" between partisan and court experts).

84. This assumes that experts are offered more cases than they wish to accept and can therefore select among those cases for compatability. This assumption is not valid for all experts who might be interested in contingent fee cases. The same self-selection for opinion compatability may occur, however, as experts with lesser caseloads decide whether to accept contingent fee cases at all. A factor in that decision is likely to be the compatability of their opinions with the cases available.

85. Sherman v. Burton, 165 Mich. 293, 296-97, 130 N.W. 667, 668 (1911) ("The [contingent fee expert's] interest in the amount of the damages furnished a powerful motive for exaggeration, suppression, and misrepresentation, a temptation . . . likely to color his testimony .... "); cf. Provident Sav. Life Assurance Soc'y r. King, 216 Ill. 416, 424, 75 N.E. 166,170 (1905) (interest of contingent fee expert affects credibility and weight of testimony).

86. See pp. 1691-92 and notes $49 \& 50$ supra.

87. N. Nordstrom, The Rights axd Rewards of the Medical Witness 6a (1962); Gair, supra note 1 , at $\$ 25$. 
attorney would therefore have a strong incentive to minimize the susceptibility of their expert evidence to inferences of bias. ${ }^{s 8}$

Susceptibility of the contingent fee expert, or of any other partisan expert, to impeachment on the basis of expert selection bias can be minimized by avoiding selection of an expert with outlandish professional opinions, insubstantial credentials, or a demonstrable history of opinion adaptability. The expert's susceptibility to impeachment on the grounds of opinion modification bias, specifically interest bias, can be minimized by assuring that the fee is, in both amount and conditions, reasonable. ${ }^{89}$ If the contingent fee is not the only means of access, the possibility of impeachment because of interest bias can be reduced by avoiding contingent fee arrangements altogether.

Judicial scrutiny of contingent fee arrangements would further reduce their potential for bias. Permitting only those contingent fees set by the trial court after settlement or judgment would ensure judicial scrutiny of the contingent fee arrangement. ${ }^{90}$ The expert's contingent fee would be restricted by the court to a reasonable amount; that is, a fee calculated from normal noncontingent compensation but adjusted to account for its contingency. ${ }^{91}$ Judicial scrutiny of con-

88. See R. KEETON, supra note $44, \S 9.8$, at $321-22$ (advising attorneys to avoid calling experts identified with litigation or paying large expert fees to minimize inferences of bias by jury); Gair, supra note 1 , at $\$ \S 19,23,24$ (advising consideration of bias, integrity, and reputation in selecting expert and avoidance of "professional experts").

89. An unreasonable contingent fee might be one which is substantially too large for the services performed, see, e.g., Von Kesler v. Baker, 131 Cal. App. 654, 655-56, 21 P.2d 1017,1017 (1933) (contract for $25 \%$ of judgment-SI 1,756-or $20 \%$ of settlement to expert witness, void as tending to impair administration of justice), or one conditioned on the content of the testimony to be given, Hough v. New York, 145 App. Div. 718, 721-22, 130 N.Y.S. 407,410 (1911) (invalidity of contract providing for fee contingent on expert's appraisal being below opposing expert's).

90. See Marine Midland Trust Co. v. Forty Wall St. Corp., 13 App. Div. 2d 118, 126-27, 213 N.Y.S.2d 689, 696-97 (1961), aff'd in part mem., 11 N.Y.2d 679, 180 N.E.2d 909, 225 N.Y.S.2d 755 (1962) (validity of experts' contingent fees upheld in part because trial court had set fees).

91. The contingent fee contract would provide that the expert receive a reasonable fee, to be set by the court and to be paid by the litigant from her settlement or judgment. See Angoff v. Goldfine, 270 F.2d 185, 188-89 (1st Cir. 1959) (factors for calculation of reasonable attorney and accountant fees); Brief for Plaintiff, supra note 2, at Is.

The trial court might react to the appearance of excessive partisan zeal or corruption on the expert's part by loweving her compensation award. Excessive venality or corruption could enter calculations under the rubric of "skill required" or "benefits accruing to the public." See Angoff v. Goldfine, 270 F.2d at $188-89$ (list of factors used in detcrmining size of fee awards). Correspondingly, the professional reputation and standing of an attorney is sometimes a factor in calculations of awarded attorney fees. Bank of China $\mathrm{v}$. Wells Fargo Bank \& Union Trust Co., 104 F. Supp. 59, 68 (N.D. Cal. 1952); Armour v. Armour, 138 N.J. Eq. 145, 162-63, 46 A.2d 826, 836 (1946).

Judicial determination of the reasonableness of the contingent fee adds an clement of uncertainty to the expert's estimate of her compensation in a contingent fee case. The effects of this added uncertainty are discussed at note 131 infra. 
tingent fees, when added to the prospect of effective impeachment, ensures that the contingent fee option would not reduce testimonial reliability substantially below levels associated with current methods of expert compensation.

\section{Economic Analysis of Expert Compensation Options}

The effects of expert compensation options on the goals of access to litigation, encouragement of settlement, and screening of frivolous suits can best be examined by means of economic analysis. The model of the litigative process employed here assumes that litigants, attorneys, and experts respond as rational economic units and thus maximize their individual utilities over time. ${ }^{92}$ Perfect information is not assumed $^{93}$ and risk preferences ${ }^{94}$ are specified when relevant.

\section{A. Access to Civil Litigation and Expert Compensation}

Access to civil litigation is limited by the prospective litigant's willingness to risk a net financial loss, by the magnitude of that possible

92. The term "utility" has been used by economists to describe the subjective "happines" of an individual, see I. LitTle, A Critique of Welfare Economics 72-78 (2d ed. 1957), or the motivating force behind consumer bchavior, see P. Saluelson, Foundations of Ecoxomic ANalysis 90-92 (1947). By definition, individuals prefer greater utility to less, P. Samuelson, Economics 433-34 (10th ed. 1976), and are assumed to make those choices that maximize the total utility they can derive from the options confronting them, see id. at 435-36. The sources of utility need not, however, be limited to goods and services. An individual may forgo material benefit in exchange for greater intangible satisfaction. See, e.g., Leff, Injury, Ignorance and Spilc-The Dynamics of Coercive Collection, 80 YALE L.J. 1, 18-21 (1970) ("spite" against one's opponent a "good"). Nonpecuniary motivations in litigation are particularly relevant to a discussion of frivolous suits. See pp. 1711-12 \& note 140 infra.

93. Perfect information means that all participants possess all of the economically relevant data in the marketplace. If the market is for expert services, then the litigant would know the prices and quality of all expert services, and could accurately assess her needs for those services. With perfect information the litigant can make the optimal choice while bearing no extra cost for gathering the information. See A. ALCHIAN \& W. Alle., Exchange and Production Theory IN USE 153-54 (1969). In the real world, few markets approach this ideal, and the costs of acquiring information on available choices are frequently significant.

The litigant and her attorney are likely to choose among experts on the basis of incomplete information. The number of experts assessed and the amount of information available on each will be limited by the resources that can be devoted to the search. Given sufficient resources, the search will continue until the cost of gathering an additional increment of information exceeds the expected gain from acquiring that increment of information. See Posner, supra note 18, at 430-31.

94. An individual is a risk preferrer if she gains more utility from a chance for a large sum than from a certainty of a smaller sum that is equal to the expected value of the gamble. For example, if an individual prefers a .1 probability of gaining $\$ 100$ to a certainty of $\$ 10$, then over the range $\$ 10$ to $\$ 100$ she is a risk preferrer. A risk avoider would prefer the certain $\$ 10$; a risk-neutral individual would be indifferent between the two options. See R. Posner, Economic ANalysis of Law 72-73 (1972). 
loss, and by its relation to the litigant's expected resources over time.95 If a prospective plaintiff has limited financial resources and is unable to finance litigation through borrowing, she faces a "budget constraint" that may deny her access to the courts. ${ }^{96}$ If the prospective plaintiff can raise the funds to finance litigation, but is unwilling to risk losing her investment (even though the gross expected value of the case ${ }^{9 \tau}$ is greater than litigation expenses), she is constrained by her inability to shift the risk of litigation..$^{98}$ The larger the risks or ex-

95. The potential litigant may be concerned not only by her eventual net financial position, but also by the timing of receipts and disbursements. The major advantage to a litigant of a contingent fee is that it matches the costs of litigation to the eventual recovery, both in terms of the amount of expenses and of the timing of payment.

96. A prospective plaintiff's financial resources are likely to be limited to a small amount of liquid resources, her expected future earnings, and possessions not easily converted into cash. Cf. A. Andreasen, The Disadvantaged Consumer 33 (1975) (discretionary expenditures of average family in 1960-61 totaled \$2883; poor family totaled \$990); G. Katona, L. Mandell \& J. Schmiedeskadip, 1970 Survey of Consumer Finances $99-100$ (1971) (42\% of families in 1970 had liquid assets less than $\$ 500$; median family liquid assets $\$ 800)$. If these resources are insufficient to cover litigation expenses, the prospective plaintiff faces an absolute barrier to court access. She must either forgo litigation or attempt to raise funds by borrowing against the expected ralue of the lawsuit.

Another problem facing potential litigants is the timing of expenditures and the ability to borrow money to pay litigation expenses. The litigant's assets may not easily be converted into cash, and the litigant may lack a borrowing option. Thus, even though the potential litigant's total resources are adequate to cover litigation expenses, she may face a barrier to litigation. Methods of paying litigation expenses-such as the contingent fee-that defer payment until the end of the adjudicatory process serve as short-term loans of litigation expenses to the plaintiff.

97. The gross expected value of the case is the total of the recoveries from all possible outcomes of the litigation after each recovery has been multiplied by its perceived probability, but before any of the expenses of the litigation are deducted. In the simplest case, with only two possible outcomes, a recovery of judgment $J$ with probability $p$, and no judgment with probability $(I-p)$, the gross expected value of the case is $p J$. If a third option of settlement recovery in amount $S$ with probability $q$ is added, with $p$ becoming the probability of success at trial given no settlement, the gross expected value of the case becomes $(1-q) p J+q S$.

In the absence of perfect information, supra note 93, expected valuc calculations by the participants in the litigation are based on their best estimates of probabilities and recovery magnitudes. See Note, An Analysis of Settlement, 22 Sr.1. L. Rev. 67, 68.69 (1969). Estimates of the same values can be expected to vary depending on who is doing the estimating, the amount of information she possesses, and her degree of optimism or pessimism. Cf. Posner, supra note 18, at $422-23$ (litigant optimism affecting settlement process). Only the differences in the plaintiff's and defendant's subjective estimates of plaintiff's probability of success at trial will be noted. Estimates of all other values $(I, S$, etc.) will be assumed to be the same, regardless of who estimates them. Accounting for differing estimates of these other values would not change the analysis presented here.

98. Paying the expenses of an unsuccessful suit may cause the litigant severe personal dislocations-such as mortgage foreclosure, substantial debt payments over a long period, or forced sale of personal property. A risk-averse litigant, see note 94 supra, will demand an expected return greater than her litigation expenses to compensate her for under. taking that risk. See Friedman \& Savage, The Utility Analysis of Choices Involving Risk, 56 J. Political EcoN. 279, 283-87 (1948) (noting that when risk is moderate, but not extravagant, risk premium is usually demanded). If risk-averse litigants do not have the option of shifting the risk of litigation, their access to the courts will be limited. 
penses of litigation, the greater the number of prospective plaintiffs who are denied access. By allowing the expert to "lend" her services to the litigant and to assume the risk of nonpayment if the litigant loses the suit, expert contingent fees reduce both the risk and the budgetconstraint barriers.

The noncontingent fee of the plaintiff-paid expert constitutes a barrier whether it is paid in advance or at the end of the litigation.99 Similarly, if the claimant believes she will in fact $^{100}$ have to reimburse the attorney's advance or guarantee of the expert fee, that amount will also constitute a barrier because it will have to be paid notwithstanding failure of the claim.

Expert fees are not an access barrier if they are paid by the government (for court-appointed experts) or by some other nonparty such as legal aid (for partisan experts). Under these systems the claimant need not make any expenditure for expert fees in order to pursue her claim, so expert compensation would not represent a risk or a threat to the claimant's budget constraint. ${ }^{101}$

If expert fees are taxed as costs to the loser, they constitute a potential barrier for any claimant with a budget constraint lower than the anticipated taxation. Although the claimant may have a good

99. The disutility from having to pay the litigation expenses of a losing suit can be prohibitively large. See note 98 supra. Even if the plaintiff has a high probability of success in the litigation, making it likely that she will be able to cover a delayed expert's fee from the settlement or judgment, a small probability of having to pay the expert in spite of failure of the claim can still prevent access. At some very high probability of success, of course, all but the most risk-averse plaintiffs will be willing to risk the remaining insignificant probability of violating their budget constraints.

An attorney or expert may charge a higher fee if payment is to be postponed because she in effect is giving the litigant a loan in the amount of her fee. This would increase the fee's tendency to act as a barrier to access.

100. Frequently an expert fee advanced or guaranteed by a contingent fee attorney is in fact contingent. See note 10 supra. The attorney-advanced expert fee may be absorbed by the unsuccessful plaintiff's attorney as part of the attorney's investment in her own contingent fec. See F. MAcKinNon, supra note 3, at 69-70, 206; D. RoseNthaL, supra note 2, at 109 (attorneys absorbing costs of litigation legally chargeable to client). It is prohibited, however, for an attorney to undertake to pay the expenses of litigation absent a noncontingent obligation for the litigant to repay her. See CPR, supra note 7, at EC 5-8, DR 5-103(B); H. DRINkER, supra note 8, at 178. Alternatively, the unsuccessful plaintiff's expert may lose the attorncy-guaranteed expert fee if the attorney can avoid the guarantec. Cf. Elliott \& Spillman, Medical Testimony in Personal Injury Cases, 2 L.iw \& Contemp. Prop. 466, 473 (1935) (payment of attending physician frequently contingent on success in litigation). But if the plaintiff believes she is liable for expert fees, they will constitute a barrier to access, even if she could in fact avoid payment. She is likely to possess such a belief since her contract with the attorney-advanced expert will be explicitly noncontingent. See p. 1686 and note 10 supra.

101. As a practical matter, however, court appointment does not necessarily eliminate the need for the parties' own experts. See p. 1696 supra. Thus the fecs of adrocate cxperts can create a barrier to access, even if the court-appointed expert is provided at no cost to the litigants. 
chance to win, the prospect that an unsuccessful suit will require a future expenditure beyond her budget constraint can still prevent prosecution of the case. ${ }^{102}$ If the expert fees to be taxed are the fees of both parties' partisan experts, the risk and budget barriers imposed are larger than when only the fee of a single court-appointed expert is taxed.

If the expert is paid a contingent fee, no access barrier is created since no expenditure for expert services is required of the claimant unless and until she wins a settlement or judgment. ${ }^{103}$ Whether an expert will accept a contingent fee, however, depends in part upon her risk preferences, her capital resources, and her assessment of the value of the case. ${ }^{104}$ If the expert's contingent fee is calculated as a percentage of the recovery in the case, ${ }^{105}$ there is some gross expected value of the case ${ }^{106}$ at which her expected contingent compensation

102. Postponement of the expenditure for expert fees to the end of the litigation may, however, improve access if the plaintiff's resources grow over time. For example, her savings or earning capacity may increase. If security for costs were required early in the litigation to assure payment, however, that security expenditure might exceed the litigant's budget constraint and thereby deny access.

103. The sum of attorney and expert contingent fees, however, could theoretically be large enough to leave the litigant with an insignificant net recovery. This would effectively deny access to any litigant whose primary motivation in litigation is pecuniary gain. If contingent fees are restricted to a reasonable amount set by the court, however, as recommended at p. 1698 supra, the court would be unlikely to allow fees that would entirely consume a successful litigant's recovery. Cf. F. Mickinnon, supra note 3 , at $41-45,183-88$ (restrictions on size of attorney contingent fees).

104. In the absence of perfect information, see note 93 supra, the quality of the expert's assessment will depend on a number of factors, including her experience in litigating similar cases, the complexity of the legal and technical issues involved, and the extent of her preemployment consultations with the litigant and attorney. Since the expert's initial contacts are likely to be with the attorney, see note 4 supra, the attorney and expert may combine legal and technical expertise in assessing the viability of the claim. See S. SPEISER \& P. RheIngor.d, supra note 32 , at $\$ 1.2$.

Whether an expert will accept a case on contingent fee may also depend on the existence of ethical prohibitions against such fees within her own profession. See note 9 supra.

105. See, e.g., Von Kesler v. Baker, 131 Cal. App. 654, 655-56, 21 P.2d 1017, 1018 (1933) (fruit and berry broker on $25 \%$ contingent fee, $20 \%$ if settled); Sherman v. Burton, 165 Mich. 293, 294, 130 N.W. 667, 667 (1911) (physician on one-third contingent fce). Attorney contingent fees are most commonly a customary or statutorily prescribed percentage of the recovery in the case. F. M.ckiswion, supra note 3, at 64-66. Presumably expert fees would use lower percentages than attorney fces. Compare expert and attorney fees in note 4 supra. If expert contingent fees were set in a reasonable amount by the trial court, they would probably be computed in part as a proportion of the recovery, since the court would consider in its calculation of a reasonable fee the value of the services to the successful litigant, i.e., the size of the recovery. See, e.g., Osguthorpe v. Anschutz Land \& Livestock Co., 456 F.2d 996, 1004 (10th Cir. 1972); Angoff v. Goldfine, $270 \mathrm{~F} .2 d$ 185, 189 (Ist Cir. 1959). But the analysis here remains valid even if the expert contingent fee is computed at a flat hourly rate, above the normal noncontingent rate. For simplicity the expert contingent fee is assumed to be a set percentage of the recovery, unless otherwise stated.

106. See note 97 supra. 
equals what her noncontingent hourly fee would have been. ${ }^{107}$ The contingent fee in cases with expected values above that equivalency point would, on average, overcompensate the expert relative to an hourly fee; those below it would undercompensate her. An expert would prefer contingent compensation for those cases with expected values above the equivalency point and hourly compensation for those below. ${ }^{108}$

Although the expert contingent fee option would improve access to the courts, it would not be available to all prospective plaintiffs. The contingent fee method of paying attorneys is unavailable to many claimants with small expected recoveries. ${ }^{109}$ Similarly, many such claimants might be unable to find experts willing to work for a

107. Although the hourly fees charged by individual experts in the same field can be expected to vary, there will be an average or customary hourly rate for experts of normal competence and reputation in a particular field. See, e.g., Maher, Impact of Devastating Injuries: Proof Relating to Economic Losses, For Both Plaintiff and Defendant, in Prictising Law Institute, The Big Negligence Case 23, 27 (1968); Speiser, Aviation Negligence Cases, in id. 45, 55.

108. If the customary percentage for an expert contingent fee is $e$ (for example, $10 \%$ of recovery), and the gross expected value of a case is $p J$, see note 97 supra, then the expert's expected contingent fee for that case is $e p J$. The expected contingent fee will differ by case in proportion to the differing gross expected values. If an expert's customary hourly rate would result in a fee of $E$ for any of a class of cases with differing expected values, then for some case expected value $e p J=E$. A risk-neutral expert would be indifferent between contingent fee and hourly compensation at that point of equivalence between the two compensation modes.

Graphically,

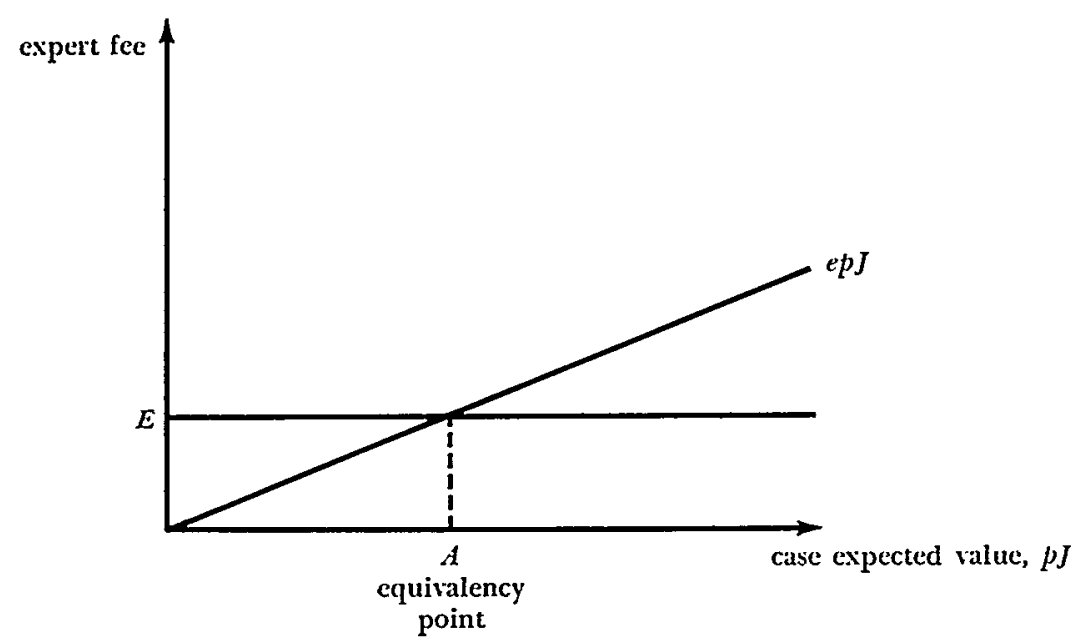

A risk-ncutral expert who could choose contingent or hourly compensation for each case by its expected value and number of hours required would charge $E$ for cases with $p J<A$ and $e p J$ for those with $p J>A$, where $A$ is the equivalency point.

109. F. MAcKinion, supra note 3, at 90, 196-97; D. Rosenthat, supra note 2, at 99. 
contingent fee. ${ }^{110}$ There is likely to be some expected value close to the equivalency point below which the expert would demand assured hourly compensation to take the case. ${ }^{111}$ Further, the impeachment prospect ${ }^{112}$ that accompanies use of contingent fee arrangements limits the degree to which that option would enhance access for budget-constrained claimants. Because the possibility of impeachment would reduce the expected value of the claim at trial, an expert may refuse to undertake some claims on contingent fee that she otherwise would have accepted.113

In sum, both free expert services and contingent fee experts increase access for budget-constrained claimants, ${ }^{114}$ although the contingent fee would not be available to claimants with low case expected values. ${ }^{115}$

110. The behavior of contingent fee experts seems likely to be similar to that of contingent fee attorneys, who choose cases on the basis of the expected value of the contingent fee, see N. Shayne, Making a Personal Injury Practice Profitable 19-28 (1972) (suggesting methods of evaluating potential recovery). The character of the market for expert witnesses can be expected to vary widely, however, depending on the degree of specialization required, the size of the relevant geographical market, and the willingness of experts with the requisite qualifications to testify. Descriptions of "professional witnesses" commonly occur in reference to physicians specializing in personal injury work. See, e.g., N. Nordstrom, supra note 87, at 52-54; cf. Van Dusen, supra note 40, at 387-88 ("corrupt 'medical expert'"). There are other types of experts, however, who derive the bulk of their livelihood from litigation. See, e.g., I R. MILLER, supra note 1 , at $\$ 10$ (various types of appraisers); id. at $\$ 17$ (automobile accident reconstruction experts); Gair, supra note 1 , at $\S 23$ (questioned document examiners). For other types of experts, the provision of testimony and other litigative services may be only an isolated or occasional endeavor.

111. If the expected value of the contingent fee is below the customary hourly wage, the expert will prefer to accept the hourly wage. See note 108 supra. A risk-averse cxpert will require higher expected returns on her contingent fee cases as a premium to compensate her for accepting any risks. As a result she will accept fewer low-value contingent fee cases. The expert may, however, accept a case with an expected value somewhat below the equivalency point. Analogous behavior is observed among attorneys working in highly competitive fields, such as personal injury litigation. See J. Carlis, supra note 22 , at $88-89$; cf. D. RosenthaL, supra note 2 , at 99 (less súccessful negligence specialists more likely to accept imperfect liability cases). Attorneys sometimes accept less profitable cases hoping that they will later be offered more profitable cases by the same client. F. MACKINion, supra note 3 , at 93 ; $c$. N. SHAYNE, supra note 110 , at 27.28 (criticizing as poor business practice).

112. See pp. 1697-98 supra.

113. The ability of the expert to make this assessment will depend, of course, on the amount of information she has. See notes 93 \& 104 supra. If the contingent fee is set in reasonable amount by the court, the added uncertainty in the size of the expert's contingent fee may cause a risk-averse expert to demand an extra premium for accepting a case on such a fee. See note 131 infra. That increases the case expected value below which the expert would demand noncontingent compensation. This would eliminate the contingent fee option in some cases, thus denying access to additional budget-constrained claimants.

114. Free expert services, howerer, have detrimental effects on settlement incentives, see p. 1706 infra, encourage frivolous suits, see p. 1712 infra, and are generally unavailable, see pp. 1687-88 \& note 3 supra.

115. The class of individual claimants with low case expected values will include more claimants with low incomes, at least in personal injury cases, because a major component 
Attorney-advanced and plaintiff-paid options create access barriers for claimants with budget constraints smaller than the anticipated expert fee. Expert fees taxed as costs create access barriers in the amount of the anticipated taxation.

\section{B. The Settlement Rate and Expert Compensation}

Prejudgment settlement of disputes is favored as a means of decreasing the demand for limited judicial resources. ${ }^{116}$ Settlement is encouraged by higher anticipated trial litigation expenses, including expert fees. Settlement occurs only if both parties perceive advantages in settling their dispute instead of continuing through trial. ${ }^{117}$

At the point at which a settlement offer exceeds the plaintiff's expected value of judgment minus the additional expenses of continuing beyond settlement through a completed trial, the plaintiff will perceive a gain from settling. That amount is the plaintiff's minimum settlement offer. Similarly, at the point at which a settlement offer is less than the defendant's expected value of the judgment against her plus the additional expenses of going to trial, she will perceive a gain from settling. That amount is the defendant's maximum settlement offer. The settlement range is the positive difference between the defendant's maximum and the plaintiff's minimum offer. ${ }^{118}$ It thus equals the defendant's expected value of the judgment minus the plaintiff's, ${ }^{119}$

of personal injury damages is lost income. See A. Covaro, supra note 4 , at 369-80. But low income claimants generally have more stringent budget constraints and thus a greater need for the contingent fee for access. See note 96 supra. Such screening of cases with low expected value by the contingent fee expert would have a regressive effect across income, denying access via the contingent fee more frequently to low income claimants. This regressive effect is bound to be less severe than the regressive effect of noncontingent fees, however, since low income claimants are more likely to be denied access if the contingent fee is not even available to them as an option. Moreover, the regressive differential in access via the contingent fee may be mitigated somewhat if funding for expert services for low income legal aid clients is available. See NLADA, supra note 35, at 8 (recommending availability of such funding). But see pp. 1687-88 \& note 35 supra.

116. See p. 1685 \& note 17 supra.

117. The following discussion of the determinants of settlement relies heavily on $H$. Ross, supra note 18; Landes, An Economic Analysis of the Courts, 14 J.L. \& EcoN. 61, 101-05 (1971); Posner, supra note 18, at 417-29; and Note, An Analysis of Settlement, 22 STIN. L. REv. 67 (1969).

118. A settlement range exists only if the defendant's maximum settlement offer exceeds the plaintiff's minimum settlement offer. If the plaintiff's minimum is larger than the defendant's maximum, there is no settlement amount that both parties prefer over continuing to trial and therefore no settlement range. If the plaintiff's minimum and defendant's maximum settlement offers are equal, the parties will be indifferent between settling at that amount and continuing to trial.

119. The parties' expected values of the judgment may diverge because of differences in information or perceived differences in the skills of their attorneys and experts, or simply because of differences in their degree of optimism. See Posner, supra note 18, at 418-20, 422-23; Note, supra note 117, at 75-76; note 97 supra. 
plus the total of both parties' extra litigation expenses for continuing past settlement negotiations through a completed trial..$^{120}$

The actual settlement amount agreed to within the settlement range depends upon the negotiating skills of the parties. ${ }^{121}$ The wider the settlement range, the more each party can gain over trial expectations by settling. ${ }^{122}$ Any factor that widens the settlement range also increases incentives for settlement. If no positive settlement range exists, the case can be expected to continue on to judgment. ${ }^{123}$

Expert compensation affects settlement by increasing the expenses of taking the case to trial. The larger the expected cost of expert services necessary for the trial, the lower will be the plaintiff's minimum settlement offer and the higher the defendant's maximum offer. This widening of the settlement range encourages settlement. If experts are provided at no cost to the parties (as is the case with statepaid, court-appointed experts or experts paid by legal aid), the parties' trial litigation expenses will decrease. The incentives to settle and, all else being equal, the settlement rate will also decrease. If the trial fees of either a court-appointed expert or the parties' own advocate experts are taxed as costs, the settlement range will reflect those fees discounted by a factor for the divergence of the parties' estimates of who will have to pay those fees. ${ }^{124}$

120. H. Ross, supra note 18, at 144-46; Posner, supra note 18, at 417-19; Note, supra note 117 , at $70-80$.

A positive settlement range is likely to exist even if the two parties' estimates of the expected value of judgment at trial are equal. Plaintiff's minimum settlement offer is determined by subiracting her trial litigation expenses from her expected judgment gain. In contrast, defendant's maximum offer is determined by adding her trial litigation expenses to her expected judgment loss to plaintiff. Thus, if both parties estimate the same expected value of judgment, any trial litigation expenses, for either party or both, will create a positive settlement range. See H. Ross, supra note 18, at 145; Posner, supra note 18 , at 419 ; Note, supra note 117 , at $72-73$.

If either party is risk-preferring or risk-averse, see note 94 supra, her settlement offer will shift to account for the risk of continuing to trial. For example, if the plaintiff is risk-preferring, her minimum settlement offer will increase to account for her higher valuation of the gamble of going to trial.

121. H. Ross, supra note 18 , at 142-44; Note, supra note 117 , at 71 .

122. The wider the settlement range, the greater the gain from avoiding trial that the parties may split between them. See H. Ross, supra note 18, at $144-46 \&$ fig. 4.1 . But cf. id. at 159, 164 (negotiations may fail if settlement range is too wide; each party unwilling to allow the other very substantial benefits from settlement). Settlement negotiations might also break down if either party is a risk preferrer: the plaintiff preferring to gamble on the possibility of a large judgment, or the defendant preferring to gamble on no judgment.

123. Settlement might occur, however, if the parties' limiting settlement offers are equal. See note 118 supra.

124. If the two parties are relatively pessimistic about their chances at trial, the defendant estimating a significantly higher probability of success for the plaintiff than the plaintiff does, they will magnify the expected cost of the taxation by each overestimating the likelihood that she will have to pay it. Such pessimism increases the settlement range 
Both plaintiff-paid and attorney-advanced compensation options add the full amount of expected trial expert fees to the settlement range. This increases settlement incentives over both the legal aid option and the court-appointed option, either state-paid or taxed. Whether taxed fees of partisan experts exceed plaintiff-paid and attorney-advanced compensation depends upon the parties' estimates of their chances of prevailing at trial. ${ }^{12 J}$

The effect of the expert contingent fee on the settlement rate depends upon how the contingent fee is calculated. It could be calculated as a percentage of recovery which increases with progressive stages of the litigation to account for increased risk and workload in cases taken to trial. ${ }^{126}$ It could also be fixed at a set percentage whether the case is tried or settled. ${ }^{127}$ An increasing-percentage contingent fee would be fixed at one percentage of the plaintiff's recovery at settlement and at a higher percentage after judgment. Similarly, a court

by lowering plaintiff's minimum and raising defendant's maximum settlement offers, and thus increases the likelihood of settlement. If, on the other hand, each party is optimistic about her chances of prevailing at trial, each will lower her expectation that she will have to pay the taxation; this would decrease the settlement range and would discourage settlement.

125. See note 124 supra. If the partics have identical estimates of the plaintiff's probability of success at trial, the settlement range for taxed partisan experts is the same as for party-paid or attorney-advanced experts. There are, however, interactions between the parties' estimates of their probability of success at trial and their expenditures on the litigation. These interactions are extremely complex and do not lend themselves to determinate solutions. This Note will thus follow Professor Posner's assumption that they do not affect the results of the settlement analysis. See Posner, supra note 18, at $419-20,437-38$.

126. The probability of recovery on the plaintiff's claim decreases, increasing the risk of nonrecovery, as the casc progresses through successive litigation stages. See Franklin, Chanin \& Mark, supra note 2, at 14 (personal injury plaintiffs gain settlement in $85 \%$ of cases closed before trial, $80 \%$ of cases closed during trial, but win only $60 \%$ of verdicts). That the expert's workload increases disproportionately as the case progresses past settlement to trial can be inferred from the fact that litigation expenses increase disproportionately to the increase in recovery as the case progresses to trial. See A. ConArD, supra note 4, at 193, fig. 6-11. For examples of increasing-percentage contingent fees for attorneys, see Contingent Fees in Personal InJury, supra note 22, at app. II.

127. For examples of constant percentage contingent fees for attorneys, see ConTINGENT Fers in Personal Injury, supra note 22, at app. II.

Another type of variable percentage contingent fee reduces the percentage of the recovery as the recovery increases in size. E.g., Rules of Practice, N.Y. APP. Div. IsT DEP'T $\$ 603.7$. For any given size of recovery, this option is similar to a fixed percentage contingent fee in that it does not depend on the stage of litigation at which recovery is gained.

A contingent fee calculated at an hourly rate will approximate either a percentage fee increasing with successive litigation stages, a constant percentage fee, or a percentage fee decreasing as recovery increases. This depends upon whether the hours required of the expert increase faster, at the same rate, or slower than the rate at which the size of recovery increases as a particular case moves beyond settlement and through trial. There is insufficient empirical evidence available to determine which of these is the most likely relationship. 
setting contingent fees in "reasonable amount" might well find that increasing levels of effort justify proportionately more generous awards. ${ }^{128}$ The size of the trial increment in the expert's contingent fee affects the size of the settlement range by lowering or raising the plaintiff's minimum settlement offer: the larger the increment to plaintiff's trial expenses, the lower will be her minimum settlement offer. The lower the plaintiff's offer, assuming no change in the defendant's maximum settlement offer, the wider the settlement range will be. The resulting increase in the size of the settlement range increases the likelihood that settlement will occur. ${ }^{129}$

It is not certain whether the expected value of the contingent fee trial increment is larger than the trial increment of an attorneyadvanced or plaintiff-paid hourly fee. On average, however, the contribution of increasing-percentage expert contingent fees to trial litigation expenses, and hence to settlement incentives, may well exceed the contribution of noncontingent hourly fees. ${ }^{130}$ This is because

128. Angoff v. Goldfine, 270 F.2d 185, 189 (1st Cir. 1959), lists the factors to be considered by the court in setting reasonable fees for attorneys and accountants in a stockholder derivative suit:

These factors are: the amount recovered ... ; the time fairly required to be spent on the case; the skill required and employed . . . ; the difficulty encountered . . . ; the prevailing rate of compensation ... ; the contingent nature of the fees, with the accompanying risk of wasting hours of work, overhead and expenses ...; and the benefits accruing to the public ....

Trial courts generally are afforded wide discretion in fixing reasonable fees. Dumas $\mathbf{r}$. King, 157 F.2d 463, 466 (8th Cir. 1946) (attorney fees). Louisiana permits the taxing of reasonable expert fees, set by the court, against the loser. LA. Rev. Stat. ANN. $\$ 13: 3666$ (West 1968). Under the enabling statute, however, courts are limited to fixing a reasonable fee on the basis of the value of the time employed and the degree of skill or learning required. Id. $\$ 13: 3666(\mathrm{~A})$; State v. Salemi, 249 La. 1078, 1083, 193 So. 2d 252, 254 (1966).

129. It could be argued that a plaintiff with both attorney and expert on contingent fee might nevertheless feel that she has nothing to lose in pressing the claim to trial rather than accepting settlement. This ignores the obvious fact that the plaintiff can lose the settlement itself by proceeding to trial, where she may lose. Furthermore, because of their contingent fee interests, the attorney and expert might pressure the plaintiff to accept the settlement. See pp. 1709-10 infra.

130. The trial increment for an increasing-percentage fee will probably be no smaller a proportion of the total contingent fee than the trial increment of a noncontingent fee is of the total noncontingent fee. The increase in the percentage of judgment recovery over the percentage of settlement recovery in an increasing percentage contingent fee must compensate the expert for two additional costs at trial. The first is the increase in hours required. Comparison with attorneys' fees indicates that such an increase in hours required may exceed the increase in recovery at trial. The second is the increase in risk associated with trial. See note 126 supra.

If expert fees are set by the court, rather than by an increasing-percentage contingent fee scale, one of the factors used to determine a reasonable fee is the number of hours of work required of the expert. See, e.g., Angoff v. Goldfine, 270 F.2d 185, 189 (1st Cir. 1959); State v. Salemi, 249 La. 1078, 1085, 193 So. 2d 252, 254 (1966). Since risk is also a factor in court fee calculations, see Angoff v. Goldfine, 270 F.2d at 189, the trial proportion of a court-calculated fee should be no smaller than that proportion of a noncontingent hourly fee. See p. 1707 supra. Similarly, if the expert's contingent fee 
contingent fees, discounted for the contingency factor, are not smaller on average than normal hourly fees for the same services; they may indeed be larger. This conclusion is supported by analogy to attorney contingent fees. ${ }^{131}$

If the expert's contingent fee is calculated as a set percentage of the recovery regardless of the stage in the litigation at which recovery is won, the only increment to expert fees from continuing to trial is attributable to the larger expected value of the trial judgment over a settlement recovery. The amount the plaintiff's expert fees will contribute to the settlement range is the contingent fee percentage times the difference between expected value at trial and at settlement. ${ }^{132}$

If the expert's best estimates of her expected fee at trial and of the value of her time and services indicate a strong personal advantage in settlement, she may attempt to influence the settlement decision through her contacts with the plaintiff's attorney during preparation of the case. ${ }^{133}$ The expert's ability to make this assessment is limited by

were set on an hourly rate, rather than as a percentage of recovery, the proportion of the total fee through a completed trial accounted for by the fee through settlement would be the same as for a noncontingent hourly fee.

131. See Angoff v. Goldfine, 270 F.2d 185, 189 (Ist Cir. 1959); Marine Midland Trust Co. v. Forty Wall St. Corp., 13 App. Div. 2d 118, 122-23, 213 N.Y.S.2d 689, 693 (1961), aff'd in part mem., II N.Y.2d 679, 180 N.E.2d 909, 125 N.Y.S.2d 755 (1962); F. MAcKinnov, supra note 3, at 159. If experts are risk-averse, they will demand larger compensation for contingent than for hourly fees to account for the extra risk involved. It has been observed that clients usually prefer to shift the risks of litigation to attorneys by use of contingent fees. Id. at 205.06; see Franklin, Chanin \& Mark, supra note 2, at 22 \& n.103 (contingent fee "almost universal" in personal injury cases).

If expert fees are set by the court in reasonable amount, the court's estimate of reasonableness adds another element of uncertainty to the expert's contingent fee. A risk-averse expert would require a premium for risking undercompensation by a parsimonious judge. That premium would increase the difference between normal hourly compensation and the expected value of contingent compensation set by the court.

132. The size of the contribution of the plaintiff's expert fees to the settlement range depends upon the magnitude of the expert contingent fee percentage and the difference between the expected judgment and the settlement.

133. The attorney is likely to have effective power to make the settlement decision for the plaintiff. F. MACKINNoN, supra note 3, at 196-97; H. Ross, supra note 18, at 82-83. See note 44 supra.

The witness's attempts to influence settlement may range from discussion of the advantages of settling and of the uncertainties of trial to conscious or unconscious minimization of the likelihood of success on the technical issues in her presettlement report. She may even threaten to discontinue her participation beyond settlement. Analogous behavior has been observed among contingent fee attorneys with constant percentage contingent fees. F. MAcKINNoN, supra note 3, at 197-98 ("[T]he lawyer's substantial interest in the recovery leads him to settle cases at a time and in an amount which suits his interests but not necessarily those of his client."); D. RosentHal, supra note 2, at 96-99 (" $[A]$ quick settlement is often in the lawyer's financial interest ... ."); H. Ross, supra note 18, at 82-83 (same); Schwartz \&. Mitchell, An Economic Analysis of the Contingent Fee in Personal Injury Litigation, 22 STAN. L. REv. 1125, 1133-36 (1970) (same; demonstrated by economic model). The attorney's behavior is not entirely analogous, however, because she is likely to exercise greater influence over the plaintiff's settlement decision. 
her imperfect information. Moreover, the effectiveness of the expert's attempts to influence the settlement decision depends upon the extent of her contacts with the plaintiff and attorney and upon the degree to which her participation is essential to effective prosecution of the case.

If the parties' expectations of effective impeachment of the contingent fee witness reduce their estimates of the expected value of the claim at trial, the size but probably not the frequency of settlements will decrease. If both parties are aware of the plaintiff's fee arrangement $t^{134}$ and of its susceptibility to impeachment, and therefore lorver their assessments of the claim's probability of success at trial accordingly, both the plaintiff's minimum settlement offer and the defendant's maximum offer will decrease. This shifts the settlement range toward smaller settlements and thus decreases the average size of settlements achieved. ${ }^{135}$ If at the time of settlement negotiations the defendant is not aware of the plaintiff's expert contingent fee, only the plaintiff's minimum settlement offer will decrease, which will widen the settlement range and encourage settlement. ${ }^{136}$ The decrease in the plaintiff's minimum offer will also lower the average settlement amount.

Expert compensation options thus have differing effects on settlement incentives. Free expert services do not contribute to trial litigation expenses. They minimize the settlement range in any individual case and minimize settlement incentives in general. Expert fees taxed as costs contribute more to expected trial litigation expenses, and therefore to settlement incentives, but less than the full amount of the taxation if each party is optimistic about prevailing at trial. If the parties are both pessimistic about prevailing at trial, expected trial litigation expenses increase by more than the amount of the taxation;

134. The compensation of expert witnesses is subject to pretrial discovery-under, for example, FED. R. Civ. P. 26(a)-for the purpose of showing her bias on cross-examination. Thayer v. Liggett \& Myers Tobacco Co., 13 Fed. Rules Serv. 2d 976, 978 (W.D. Mich. 1970) (defendant required to answer interrogatories on compensation and other relationships of its experts with itself, other tobacco companies, and the Tobacco Institute); Da Silva v, Moore-McCormack Lines, Inc., 47 F.R.D. 364, 365 (E.D. Pa. 1969) (dictum) (interrogatories on compensation of an expert in prior cases to show bias generally allowed, but discovery denied); cf. United States v. 364.82 Acres of Land, 38 F.R.D. 411, 415-16 (N.D. Cal. 1965) (deposition of plaintiff's experts for preparation for cross-examination allowed).

135. Whether the settlement range will be wider will depend on the relative sizes of plaintiff's and defendant's assessments of the effect of the contingent fee on the plaintiff's probability of success at trial. If, for example, the plaintiff believes the effect will be large while the defendant believes it will be small, the plaintiff's minimum settlement offer will drop more than the defendant's maximum, and thus will widen the settlement range.

136. The plaintiff's minimum settlement offer will decrease only to the extent that she fears discovery of her expert's contingent fee by the defendant. 
the settlement range and therefore the incentives to settle also increase. Attorney-advanced and plaintiff-paid expert fees contribute in full amount to trial litigation expenses and increase settlement incentives over free expert services.

Contingent expert fees seem likely to increase settlement incentives. An increasing-percentage contingent fee would probably increase trial litigation expenses and thereby increase settlement incentives over any noncontingent option. A constant-percentage contingent fee may cause the expert to pressure the plaintiff to settle. The prospect of impeachment of the contingent fee expert for her interest in the litigation would tend to decrease the size of settlements and perhaps to increase their frequency, regardless of how the contingent fee is calculated.

\section{Frivolous Suits and Expert Compensation}

Frivolous suits are defined as claims of such insubstantial merit as to have negligible probability of success at trial, as assessed by the trial court. ${ }^{137}$ They are disfavored as an unnecessary burden on limited judicial resources. ${ }^{138}$ Various procedural devices, such as motions to dismiss and motions for summary judgment, are designed to screen out such suits. ${ }^{139}$

137. See Fletcher v. Young, 222 F.2d 222, 224 (4th Cir.), cert. denied, 350 U.S. 916 (1955) (suit attempting to reopen conclusively adjudicated issues held frivolous and dismissed); B. Christensen, Lawyeks for Peorle of Moderate Mfeans 145 (1970) (social value of litigation related to legitimacy of claims asserted; "stirring up of frivolous or fraudulent claims is undoubtedly evil"); cf. Strong v. Sproul, 53 N.Y. 497, 499 (1873) (“A frivolous answer is one so clearly and palpably bad as to require no argument .....")

Nuisance or strike suits are a variety of frivolous suits that use the threat of substantial litigation expenses to gain a settlement unjustified by the merits. Adams v. Crown Coal \& Tow Co., 198 III. 445, 450, 65 N.E. 97, 99 (1902) (dictum) (settlement not valid "if the claim to the right was put forth as a mere pretense, to extort money or to induce the execution of the agreement"); Roach v. Franchises Int'l, Inc., 32 App. Div. 2d 247, 250, 300 N.Y.S.2d 630, 633 (1969) (defining stockholder "strike suit" as action brought in hope of gaining attorney fees or large settlement, but with no intention of benefiting corporation); Shapiro v. Magaziner, 418 Pa. 278, 284, 210 A.2d 890, 894 (1965) (same); see H. Ross, supra note 18, at $199-211$ (describing insurance company practices of settling suits without liability, in response to "danger value" or "nuisance value" of the claim). Nuisance suits differ from other frivolous suits only in the plaintiff's awareness of the frivolity of the claim and intention not to go to trial if settlement fails.

138. Waldron v. British Petroleum Co., 38 F.R.D. 170, 176 (S.D.N.Y. 1965), aff'd sub nom. Waldron v. Cities Service Co., 361 F.2d 671 (2d Cir. 1966), aff'd sub nom. First Nat'l Bank v. Citics Scrvice Co., 391 U.S. 253 (1968) ("policy against the undue harassment of a litigant through a spurious lawsuit"); Berkal v. M. De Matteo Constr. Co., 327 Mass. $329,333,98$ N.E.2d 617, 620 (1951) (unreasonable and unnecessary litigation not to be encouraged); Spector, supra note 6, at 332 (unnecessary cases increase court congestion).

139. Fletcher v. Young, 222 F.2d 222, 224 (4th Cir.), cert. denied, 350 U.S. 916 (1955) (dismissal); Waldron v. British Petroleum Co., 38 F.R.D. 170, 176 (S.D.N.Y. 1965), aff'd sub nom. Waldron v. Cities Service Co., 361 F.2d 671 (2d Cir. 1966), aff'd sub nom. First Nat'l Bank v. Cities Service Co., 39I U.S. 253 (1968) (summary judgment); Gift Stars, Inc. v. Alexander, 245 F. Supp. 697, 701 (S.D.N.Y. 1965) (punitive taxation of court costs). 
A plaintiff is more likely to press her frivolous claim the greater the total expected value she perceives for it. ${ }^{140}$ Faced with a choice of expert compensation options, the frivolous plaintiff will choose the option that gives her claim the greatest net expected value.

By imposing expert costs on the plaintiff, the plaintiff-paid and attorney-advanced compensation options tend to discourage frivolous suits. Expansion of free expert services, on the other hand, would tend to encourage frivolous suits by minimizing the expenses of litigation and by increasing the perceived net expected values of frivolous claims. $^{141}$ Taxation of partisan expert fees against the loser would discourage frivolous suits relative to present practices by substantially increasing expected litigation expenses to a plaintiff with an insubstantial probability of success. ${ }^{142}$ The expert contingent fee probably would not increase the incidence of frivolous suits. In cases with low expected values, the expert would insist on a noncontingent hourly fee and thus would make the availability of the contingent fee irrelevant. ${ }^{1+3}$ The expert therefore would refuse to take many frivolous suits. ${ }^{144}$

By eliminating the commitment to pay expert expenses when the suit is unsuccessful, the contingent fee may encourage frivolous suits with expected values large enough to attract experts willing to accept contingent compensation. ${ }^{14 \bar{s}}$ The contingent fee, by promoting settle-

140. This assumes economically rational behavior. See p. 1699 supra. The assumption of economic rationality, however, does not exclude other motivations for litigation. See note 92 supra. Frivolous suits might be motivated by a variety of nonpecuniary factors, including spite, a feeling of being wronged, or even political or social expression. See Leff, supra note 92 , at $18-21$ (spite and feeling of being wronged). But cf. R. HuNTING \& G. Neuwirth, Who Sues IN NEW YORK CiTr? 86-89 (1962) (attitudes of personal injury claimants toward insurance companies, lawyers, and compensation system have no effect on decision to sue). Whatever the plaintiff's primary motivation in initiating a frivolous suit, however, she will be further encouraged by any factor which increases its potential economic value, all else being equal.

141. Budgetary constraints on a legal aid office, however, may cause it to screen frivolous suits. See NLADA, supra note 35, at 5-6.

142. Taxation of litigation expenses against the loser is frequently mentioned as a means of deterring frivolous suits. E.g., F. MAGKINNon, supra note 3, at 142-43; Comment, Court Awarded Attorney's Fees and Equal Access to the Courts, 122 U. PA. L. REv. 636, 651 (1974); cf. Posner, supra note 18, at $438-39$ (taxation of costs may screen out some small but meritorious claims).

143. See pp. 1703-04 supra.

144. Cf. F. Mackininon, supra note 3, at 201, 206 (contingent fee attorneys screen out cases in which chances of recovery are slight); D. Rosenthal, supra note 2, at 99 (same); N. Shayne, Making a Personal Injury Practice Profitable 27-28 (1972) (advising contingent fee attorneys to reject poor liability cases).

145. Frivolous suits are defined only on the basis of their probability of success at trial. See p. 1711 supra. In order to attract a contingent fee expert, therefore, a frivolous suit must have large damages if liability is found, which would inflate the expected value at trial. 
ment, would also encourage frivolous suits brought with the aim of gaining a settlement unjustified on the merits. ${ }^{146}$ The prospect of effective impeachment of the contingent fee expert, however, would reduce the expected value of the plaintiff's claim. This would encourage the expert to screen more cases and would discourage plaintiffs from pursuing their frivolous claims. ${ }^{147}$

The contingent fee could also increase the expected value of the case by increasing the likelihood of settlement. If the contingent fee increases the probability of settlement more than it decreases the size of settlements, see pp. 1709-10 supra, it will increase the expected value of settlement and, as a consequence, increase the expected value of the case, see note 97 supra. This will shift some cases above the expert's resistance point, thus limiting the contingent fee expert's effectiveness as a screen against frivolous suits.

146. The expected value of the frivolous claim could increase sufficiently to avoid screening, see note 145 supra, if conditions are conducive to gaining a nuisance settlement. See note 137 supra. Encouragement of such nuisance suits results from encouragement of settlement, since wider settlement ranges allow greater potential for gain through skillful negotiation by the nuisance plaintiff. A frivolous suit will be most useful in extorting a settlement when the defendant's litigation expenses are high, the plaintiff's litigation expenses are low, and the defendant has a higher assessment of the expected value of the claim at trial than does the plaintiff. See generally H. Ross, supra note 18, at 199-211. High defendant litigation expenses and relative pessimism of the parties both widen the settlement range, see pp. 1705-06 \& note 124 supra, and make settlement more attractive to the defendant confronted with a nuisance claim. Low litigation expenses for the plaintiff aid the nuisance claim by minimizing the plaintiff's risk and by increasing the credibility of her threat to press the defendant to trial.

The contingent fee may well encourage nuisance suits, since the plaintiff need not pay expert fees except out of the nuisance settlement. But the plaintiff may prefer noncontingent hourly compensation over a contingent fee for support of a nuisance claim if use of hourly compensation increases the expected value of the claim. This would occur if the perceived likelihood of settlement is high and the contingent fee is substantially more expensive than assured compensation. See pp. 1707-09 supra.

Nuisance suits may also be encouraged by the prospect of effective impeachment of contingent fee experts. If the defendant is not aware of the contingent fee arrangement, the widening of the settlement range from the decrease in the plaintiff's minimum settlement offer will encourage nuisance suits. If the defendant is aware of the contingency, her estimation of the trial expected value of the claim will decrease. If her expected litigation expenses remain the same, that decrease may increase her preference for settlement by lessening the size of the prospective settlement compared to her litigation expenses. See H. Ross, supra note 18, at 204-11 (defending insurance adjusters willing to settle low expected value claims to avoid disproportionate processing costs). Reduction in the defendant's assessment of the expected value of the case at trial might reduce the settlement range, however, if the defendant believes that a contingent fee expert would be susceptible to effective impeachment at trial. See note 135 supra. Furthermore, repeating defendants may not be willing to settle strike suits if they believe their intransigence in a few cases will be rewarded by a decrease in such claims. Compare Posner, supra note 18 , at $433-36$ (dismissing settlement of nuisance suit as irrational for repeat defendant) with H. Ross, supra note 18, at 204-11 (in spite of rhetoric to contrary, insurance companies regularly pay nuisance settlements).

In summary, it is possible that nuisance suits will be encouraged by expert contingent fees. But the risk of nuisance suits is implicit in any policy that facilitates settlement. The procedural devices used to screen other frivolous suits would have to be relied upon to limit this unfavorable effect of allowing expert contingent fees. See p. 1711 \& note 139 supra.

147. See p. 1704 supra. 


\section{Conclusion}

Contingent fees for expert witnesses should be permitted when set in reasonable amount by the trial court. The court's participation, coupled with the prospect of effective impeachment, would minimize the danger of bias in expert testimony. The contingent fee would improve access to civil litigation for budget-constrained and risk-averse claimants. Removal of the prohibition on expert contingent fees would, of course, also make available that payment option to litigants for whom access is not a problem. This is not, however, a substantial concern, for the threat of effective impeachment would encourage litigants who can afford noncontingent compensation to avoid contingency. Nevertheless, some litigants with a choice may select contingent compensation in spite of its harm to the expected value of their claims. But, by encouraging settlement of those claims, the contingent fee option would relieve some of the burden on the adjudicatory system added by improved access. 